\title{
LENDO E AGENCIANDO IMAGENS: \\ O REI, A NATUREZA E SEUS BELOS NATURAIS*
}

"mar não tem desenho, o vento não deixa..."

Guimarães Rosa

\section{INTRODUÇÃO: ILUSTRAR É ENFEITAR}

\begin{abstract}
Durante muito tempo, e como bem definiu o historiador Jacques Le Goff (2010), as ciências sociais, de uma maneira geral, viveram do imperialismo dos documentos escritos. O suposto era que a investigação social, sua própria genealogia, seria pautada em manuscritos escritos, como se todas as demais fontes estivessem excluídas da agenda desses profissionais, ou ocupassem papel subalterno e apenas complementar. Sobretudo as imagens funcionariam como "ilustrações", no sentido de que apenas "adornam" uma tese previamente conhecida; exemplificam conclusões já estabelecidas.
\end{abstract}

Na definição do dicionário Houaiss, o termo ilustrar se refere "a uma imagem que acompanha o texto". "Acompanhar" um ensaio escrito não significa, por suposto, interpelá-lo, pois quem acompanha apenas segue; dá continuidade. Uma "ilustração" seria, assim, um recurso pictórico utilizado para exemplificar ou sintetizar argumentos desenvolvidos, a partir e na narrativa. A própria palavra vem do termo "ilustrar", do latim ilustro, que significa lançar luz, tornar claro, dar brilho, enfeitar, ver. A convenção acabou, pois, por normalizar usos, e fez da "ilustração" - geralmente uma imagem pictórica, figurativa -, um expediente colado à sua definição primeira: quase um "decor". E entre cientistas sociais rotinizou-se a prática de incluir imagens com o objetivo de deixar o texto mais agradável, ou enfatizar uma concepção já definida. 
Não por coincidência é comum encontrar uma utilização um tanto conservadora das imagens em nossos ensaios. Um "clássico" é colocá-las em apêndices ao final de livros e textos, como se elas não precisassem de maiores explicações ou se não fosse necessário escrutinar suas origens sociais, clientelas, contextos, recepção ou circulação. Mais ainda, elas em nada interfeririam na obra, e por isso poderiam ficar dispostas no seu final, para mero deleite do olhar.

Outro uso bastante corriqueiro tem sido incluir ilustrações no decorrer dos textos, mas, sem as devidas referências. Ora, justamente nós que temos orgulho da "arte de bem citar", esquecemos de guardar o mesmo rigor no caso das fontes imagéticas. Incluir autoria, data, dimensão, acervo, título e toda uma série de dados que fazem parte da própria descrição desses documentos visuais são procedimentos pouco usuais nos textos da nossa área. Ou seja, não parece ser muito relevante referenciar esse tipo de documento, ou dar tratamento paralelo ao que oferecemos às demais fontes escritas utilizadas. Mais uma vez, o suposto, silenciosamente partilhado, é resultado de uma prática comum, que supõe serem esses documentos "menos sérios"- quiçá mais próprios a outras áreas -, não carecendo, portanto, de tanta precisão na citação ou no estabelecimento da origem.

Com os recentes recursos virtuais, as possibilidades de utilização multiplicaram-se e com elas também as formas de incluir imagens em palestras, por exemplo. E não são poucas as vezes que apresentamos power points repletos de imagens (mais uma vez sem a delimitação das fontes), a despeito de não sabermos bem o que fazer com elas. Apresentamos os slides junto com os textos? Deixamos para o final quando resta pouco tempo? Interpretamos as imagens ou só as usamos como recurso de exposição? Novamente, o tal uso conservador se manifesta, com os recursos iconográficos sendo antes entendidos como expediente para captar a atenção do público, e menos como uma fonte de pesquisa que precisa, ela mesma, passar pela verificação crítica.

Paradoxalmente, já faz certo tempo que se abriram novas possibilidades documentais, que vêm expandindo a própria noção de arquivo e de acervo. Para além das bases escritas, se arrisca produzir novos conhecimentos a partir da análise de moedas, lápides, objetos de cultura material de uma maneira geral, fontes literárias, obras de teatro, telas, esculturas, imagens de jornal, cartazes, caricaturas e, tomando um lugar cada vez mais importante, fotografias. No entanto, vale a pena acentuar como continuamos encontrando um lugar "subalterno" para esse tipo de material, como se existisse uma hierarquia interna às fontes: em primeiro lugar os registros escritos, em segundo (e de maneira distanciada) as imagens, e de maneira alargada.

Mas penso que é chegada a boa hora de "lermos imagens" em sentido paralelo ao que destrinchamos um documento amarrotado, um texto clássico, um documento cartorial, uma notícia de jornal. A ideia central deste artigo 
é, assim, quase ingênua, se não fosse "atrevida" na provocação que ela pretende instigar: vasculhar usos de imagens não como ilustrações, mas como documentos que, assim como os demais, constroem modelos e concepções. Não como reflexo, mas como produção de representações, costumes, percepções, e não como imagens fixas e presas a determinados temas ou contextos, mas como elementos que circulam, interpelam, negociam. Uso o termo "representação", que tem com certeza uma larga tradição e merece uma série de concepções políticas, sociológicas, semióticas e estéticas, antes com o sentido que Mitchell (2009: II) lhe conferiu "de estar em lugar de e atuar por" do que como "coisa" fixa e essencial. Nesse sentido ele permite relacionar texto e imagem; questões éticas, do conhecimento e do poder. Menos do que uma teoria da imagem, a sugestão é de dar "imagem à teoria", no sentido de ela se comportar como uma privilegiada instância formadora de representações. Dessa maneira, o conceito de representação é, antes, entendido aqui como processo e relação, incluindo-se em seu escopo cultura política, sistema de intercâmbios e transferência de valores, imaginários utópicos e realidades pragmáticas (Mitchell, 2009).

Pretende-se lançar mão de alguns exemplos, mas de um em especial: a construção da representação da Nação e do Estado durante o Segundo Reinado, nomeadamente a partir da seleção e circulação de certas imagens, e da exclusão de outras. De um lado, indígenas, a natureza e o soberano - ele próprio convertido em objeto de construção imagística e imaginária - aparecerão como partes de um "triângulo nacional", por vezes intencionalmente acionado, por vezes incorporado de maneira mais involuntária. Matéria dileta dos discursos nacionais e românticos do XIX, a "natureza e os naturais" virarão símbolos do novo Estado, tendo como figura central - a organizar o movimento - o próprio monarca Pedro II. De outro lado, porém, não há como esquecer das imagens que restavam silenciosamente, resultantes do largo e estabelecido sistema escravocrata vigente no país. Espécie de sombra a alimentar e esconder os alicerces desse grande projeto nacional, os escravos foram apreendidos de muitas maneiras - nas fotos exóticas vendidas fora do país, nos ensaios frenológicos e científicos, na convenção das amas de leite -, mas, sobretudo, de maneira desavisada e silenciosa e, como afirma Daniel Aarão Reis, muitas vezes "o silêncio é uma forma de memória" (Reis, 2014: 208). Se nesse contexto camponeses se transformavam em uma representação positivada para a construção das novas nacionalidades - sendo destacados seus costumes e hábitos não conspurcados pelos "vícios das cidades" - mais difícil seria incluir os escravos nesse mesmo "pacote". Igualmente convertidos em objetos exóticos e exotizados, eles terão seus corpos expostos e "pacificados", recebendo tratamento paralelo, sobretudo da parte de fotógrafos, mas permanecerão excluídos do discurso visual oficial. Terão presença cativa nos cartes de visite que visavam o exterior, mas, no país, causariam contínuo mal- 
-estar. Nesse processo, e como veremos, um conjunto amplo de imagens terá grande relevância. Dessa vez, porém, elas conduzem a reflexão, e não o contrário. Mais ainda, como um relógio com ponteiros bem azeitados, cada elemento estará devidamente em seu lugar.

Diz o crítico de arte Michael Baxandall (2006) que o público cria as suas obras, mas que o contrário também é fato: as obras fazem seu público. Se assim for, há uma relação muito mais ativa do que passiva entre imagens e contexto. Menos do que só registros imediatos de seu momento, elas ajudam a formar percepções coletivas, criar conceitos difundidos, selecionar registros de realidade. É certo que não há maneira (e muito menos razão) de evitar entender as imagens inseridas em seus contextos. Mas também não há como tomar diante delas um partido neutro, naturalizado. Imagens têm autoria, tempo e agência.

$\mathrm{Na}$ verdade, e pensado em outros termos, esse tipo de debate nada tem de naîve, uma vez que, à sua maneira, ele é parte de uma polêmica mais ampla que vem opondo estudiosos adeptos de modelos formalistas a outros mais vinculados a perspectivas historicistas. Isto é, distanciou estudiosos da arte mais preocupados e atentos às convenções, marcos e estilos próprios a esse tipo de campo, de intérpretes que insistem em destacar as dívidas históricas e sociais que uma imagem carrega consigo. Minha intenção aqui é menos audaciosa, talvez mais metodológica e focada em preocupações próprias das ciências sociais. Não se trata de refazer a teoria, que por certo é vasta e não caberia no escopo deste ensaio. Nosso fito é, antes de mais nada, investir em alguns exemplos e possibilidades analítico-interpretativas, com o objetivo de entender como, em momentos delimitados, as imagens perdem o papel secundário, para ganharem a cena central.

\section{A NEBLINA DE LONDRES OU QUEM FOI QUE INVENTOU O FOG}

Começo por uma perspectiva que talvez seja para nós, cientistas sociais, a mais distante e estranha: a formalista, aquela que aposta na concepção de que uma tela deve muito mais a outra do que a seu contexto imediato. Ou seja, que obras de arte dialogam com outras obras, com tradições e modelos preexistentes e, por isso mesmo, como afirma o historiador da arte Ernest $\mathrm{H}$. Gombrich, "as imagens falam entre si" (I995: 63). Nada como recorrer aos exemplos, quase programáticos desse autor. Segundo ele, antes de o pintor James M. Whistler pintar e divulgar suas telas, não havia neblina em Londres. Gombrich não acredita, logicamente, que inexistia em Londres o fenômeno climatológico que hoje conhecemos como "neblina", com os céus britânicos sempre em tons de cinza e uma sensação de névoa pairando no ar. O que o autor buscou explicar, com essa consideração por certo idiossincrática, é que foi um pintor quem construiu o "sentimento coletivo" de se sentir cinza quan- 
do na capital britânica. Segundo essa interpretação, teria sido a partir das pinturas de Whistler que se difundiu uma visão geral de que, quando em Londres, o tempo é feio. Nesse caso, foi a pintura que rotinizou a definição e uma certa identidade local, e não o contrário.

É também Gombrich quem explica que foi Constable o criador da representação dos campos verdejantes da Inglaterra. Mais uma vez, não é o caso de imaginar que não existem campos (e por sinal verdes) na Inglaterra, mas que foi um artista quem tratou de gravar e dar um sentido de nacionalidade ao aspecto rural da Inglaterra. Como mostra Raymond Williams, não há campo sem cidade. A representação do ambiente rural é, no limite, uma relação que só se define a partir de seu par oposto: a cidade (Willians, I989). A recorrente evocação nostálgica de um passado rural de abundância e de suprema felicidade, só pode ser entendida, pois, em paralelo com as mudanças decisivas ocorridas em Londres nos séculos XVIII e XIX. Mas se a análise de Williams guarda uma perspectiva e preocupação sociológicas, já a de Gombrich busca dar anterioridade à pintura. Sabemos que a eleição de traços de identidade cimento para os discursos de nacionalidade - é sempre uma construção social e política. Mas importa acentuar não apenas a opção de Constable por retratar campos perfeitos e imaculados, como a popularização dessas telas por parte do público inglês, de modo a transformá-las em ícones de uma Inglaterra, a esse tempo, cada vez mais urbanizada. No lugar das poluídas e industriais cidades inglesas, que em finais do XIX estavam longe de serem entendidas como exceção, telas desse pintor figurariam como exemplos de nacionalidade no lugar de outras. Essas paisagens naturais - que incluíam montanhas verdejantes, pastos, lagos, jardins -, para além de atingirem o gosto da clientela, acabaram por se constituir numa espécie de "essência" inglesa. Aí residiria inclusive, e para usarmos os termos de Simon Schama (1996), a diferença entre dois conceitos à primeira vista idênticos: natureza e paisagem. A paisagem é uma representação da natureza, observada a partir dos olhos da cultura, do afeto e refeita a partir de construções sociais. Por certo já existia uma consolidada tradição pictórica de quadros versando sobre paisagens na Inglaterra, mas é nesse momento que elas viram exemplo e molde nacional. Mais ainda, a novidade gera uma subversão de valores. Parece que quando Constable tomou parte de um júri na Academia de Londres, por engano uma pintura sua foi trazida para análise. Um outro membro, mostrando contrariedade diante da tela, reclamou com um sonoro: "tirem essa coisa verde de nossa frente!" Segundo Gombrich, o verde era considerado kitsch; ou melhor, era tomado como uma cor de mau gosto, antes de Constable. Nesse caso, teria sido um pintor aquele que além de se servir da cor verde, ofereceu a ela um novo sentido e lugar. Verde combina com as cores dos campos da Inglaterra! (Gombrich, 2007: 35).

Imagens se referem a outras imagens, assim como utilizamos imagens para mostrar o que é uma imagem. Obras como as de Magritte, Jasper Johns, 
Andy Warhol, só para ficarmos com os exemplos mais óbvios, mostram didaticamente o que todas as telas demonstram: que a arte é sempre uma prática de autorreferência, que é capaz de refletir sobre si mesma, e que, sobretudo, toda "obra de arte está infectada de outra arte" (Lipman \& Marshall, I976: 9).

$\mathrm{Na}$ dificuldade que temos em enfrentar representações visuais, estaria o que Rorty chamou de nossa "obsessão pelo modelo da imagem como uma figura transparente" e "real". Para ele o "espelho" é uma verdadeira tentação criada pelo cientificismo e pelo positivismo diante das iconografias. As imagens constituiriam, ao contrário, um ponto singular de fricção e desassossego atravessando uma série de campos de investigação intelectual. ${ }^{1}$ Além do mais, artes visuais são "sistemas de signos", formados por convenções que os quadros, fotografias, objetos escultóricos, monumentos arquitetônicos carregam como formas de "textualidade" e de "discurso". Teríamos assim como que "avenidas de referências" quase formalizadas em sistemas de notação, convenções figuradas, alfabetos, caligrafias, caracteres e uma série de unidades de significados bastante estabelecidos e "legíveis". Não me parece que seja o caso de voltar ao conceito de "mímesis": ao menos daquele que trata da representação como cópia e correspondência (Bhabha, 2002). Talvez pudéssemos arriscar o conceito de "mímica" usado por Homi Bhabha, no sentido de alteração, releitura e tradução. O mais importante é investir nesse jogo complexo de visualidades, com seus aparatos, discursos, corpos e jogos de figura. Por outro lado, a entrada em cena da ideia de recepção e do próprio expectador deve se constituir numa questão tão complexa como as "formas de leitura" - decodificação, deciframento, interpretação -, e que nos leva a problematizar a própria experiência visual, ou mesmo nosso verdadeiro "analfabetismo visual".

Para tanto, não é preciso que fiquemos restritos aos exemplos vindos de fora, muito menos evitar contemplar a dimensão social, sempre igualmente presente e constitutiva das imagens.

\section{O REI, A NATUREZA E SEUS NATURAIS: UM TRIÂNGULO NACIONAL}

No país, quiçá um dos exemplos mais acabados (ou ao menos precursor) do uso da imagem para produzir realidades - no caso a própria nacionalidade tenha se dado no Segundo Reinado, quando Pedro II implementa um projeto nacional romântico, muito pautado em recursos e material visual: primeiro, por meio de grandes telas criadas pela Academia Imperial de Belas Artes e, depois - ou conjuntamente a partir da segunda metade do XIX -, pelo incentivo e disseminação da fotografia. Numa nação como o Brasil, em que a fotografia entrou cedo, já nos idos de I839, e que compartilhou com outros países a múltipla invenção da técnica, a partir das experiências de Hercule Florence, o impacto seria profundo (ver Kossoy, 2000). Ainda mais porque o próprio 
soberano Pedro II se gabava de ser o primeiro monarca fotógrafo, além de contratar e financiar uma série de profissionais da área, ou mesmo apoiar grandes casas dedicadas ao ofício. ${ }^{2}$ Com isso a fotografia ganharia um papel fundamental, seguindo o rei de perto: o monarca e sua família seriam clicados nas mais diversas situações, assim como Pedro II faria questão de colecionar suvenires da terra, sobretudo a natureza dos trópicos e seus belos habitantes das selvas. Interessante pensar nos artifícios e nas potencialidades da operação: o monarca não só se comporta como mecenas da fotografia, como atua enquanto fotógrafo e cria uma coleção com critérios próprios. O objetivo era selecionar imagens desse Império e, assim, difundi-lo. Selecionar significava incluir, mas também excluir, e, assim, na contramão do exercício dos viajantes e fotógrafos que trabalhavam sem o patrocínio (e o controle) real, nesse caso havia intencionalidade e desejo de gravar uma só imagem. Uma imagem que dignificasse a nação.

E a fotografia permitirá agilizar um modelo de representação já testado na literatura palaciana e nas telas da Academia Imperial de Belas Artes: o indigenismo romântico. ${ }^{3}$ Tratava-se de implementar um projeto nacional pautado em duas grandes bases - a natureza e seus naturais - e tendo como vértice do triângulo o próprio monarca, a orquestrar tal projeto. Diz Anne McClintock (2003, 2010) que os "nacionalismos têm raça" e no Brasil o modelo vertebraria de forma, digamos assim, harmoniosa. De um lado, o país seria representado por seus indígenas, devidamente estilizados, por oposição aos escravos transformados em tipos, e retirados desse discurso visual que selecionava identidades e jogos de pertença. Modelos de nacionalidade são modelos imaginários, que fazem uso alargado de elementos como censos, mapas, jornais e também imagens, sempre visando a construção de uma comunidade que se reconhece como tal (Anderson, 2009). Já o sistema escravocrata não era propriamente um elemento a alardear, sobretudo a partir dos anos I870, quando o Brasil foi se convertendo num dos últimos países a admitir tal regime de trabalho no mundo ocidental. Muito pelo contrário, o escravismo representava o oposto da imagem civilizada e progressista que o país procurava veicular. Melhor apostar na natureza exótica dos trópicos e em seus habitantes primeiros, e deixar escravos como sombras, silêncios e sobras da representação. A cada qual o seu lugar.

\section{GIGANTE PELA PRÓPRIA NATUREZA}

Desde os tempos em que o Brasil era ainda uma América portuguesa, já era reconhecido por sua natureza sem igual: um novo Éden, uma terra da promissão. O novo território foi logo considerado um imenso "gigante tropical" habitado por muitas raças e grupos de origens variadas: um posto avançado para a observação dos viajantes do XVI, dos naturalistas do XVIII e dos cientistas 
do XIX, cada vez mais interessados nessa espécie de laboratório "natural" e, ademais, "racial". Paraíso para alguns, inferno para muitos, a visita ao país por fotógrafos itinerantes que varreram o Brasil de ponta a ponta, foi motivada a princípio pelo desejo de conhecer de perto esse Império, dado a costumes, climas e políticas em tudo distintas.

E não por acaso, a natureza dos trópicos (por vezes plácida, por vezes sublime) ocupou papel destacado desde os primeiros registros dos viajantes. Cachoeiras, florestas virgens, palmeiras imensas, mas também animais selvagens ou domesticados, frutas e flores fizeram parte do primeiro desenho captado do Brasil, que era visto - antes mesmo que esses profissionais estrangeiros da fotografia por aqui chegassem -, como um local exótico por excelência.

Com o advento da fotografia, o espetáculo seria multiplicado a partir dos recursos da nova técnica. Cachoeiras grandiosas fizeram a alegria desses fotógrafos que buscavam flagrar o descontrole dos trópicos e usavam como réguas e instrumento para aferição da proporção, pequeninos escravos, ainda mais diminutos diante da imensidão da natureza. Descontrole e controle, exotismo por oposição ao conhecido eram chaves para o sucesso dessas imagens recebidas de maneira ávida pela clientela estrangeira. Interessante pensar que, por conta do risco ou do uso disseminado da escravidão nos costumes da terra, cativos - que eram de certa maneira excluídos da representação oficial - acabaram sendo utilizados para avalizar a escala avolumada da natureza. Anônimos, quase invisíveis, eles servem para dimensionar a paisagem, mas nela não interferem. São figuras silenciosas.

O que contava era mesmo a paisagem dos trópicos. Se desde as grandes viagens, e mesmo antes delas, o desenho como gênero se voltou para a paisagem natural e humana, o auge desse movimento de elevação da natureza como "paisagem" - feita do ambiente físico, humano e animal -, se dá em pleno século XIX, quando, na conformação de modelos identitários, a representação do território natural assume o lugar da própria nacionalidade. Goethe em seu diário sobre a Itália deixou vários registros a comprovar como a paisagem é elevada, nesse contexto, a um valor, e assim incluída nos discursos nacionais. O filósofo alemão trocaria a ideia de país pela noção romântica da "pátria em que nascemos", dispondo a paisagem como elemento central.

Alcançamos então uma elevação, abrindo-se diante de nós a mais ampla vista. Nápoles em toda a sua magnificência, milhas e milhas de casas enfileiradas à margem plana do golfo, promontórios, línguas de terra, paredes rochosas, depois as ilhas e, atrás delas, o mar. Tudo isso oferecendo uma paisagem encantadora. Uma cantoria medonha, antes um grito ou um uivo de alegria proveniente do rapaz em pé atrás de nós, me assustou e perturbou [...]. Por algum tempo, ele não se mexeu; depois, bateu-me de mansinho nos ombros, esticou o braço direito entre nós, o dedo indicador levantando e disse: "Signor, perdonate! Questa è la mia patria!". E aquilo surpreendeu-me de novo. A mim, pobre homem do Norte, não pude conter as lágrimas que me afloraram aos olhos (Goethe, 1999: 262). 


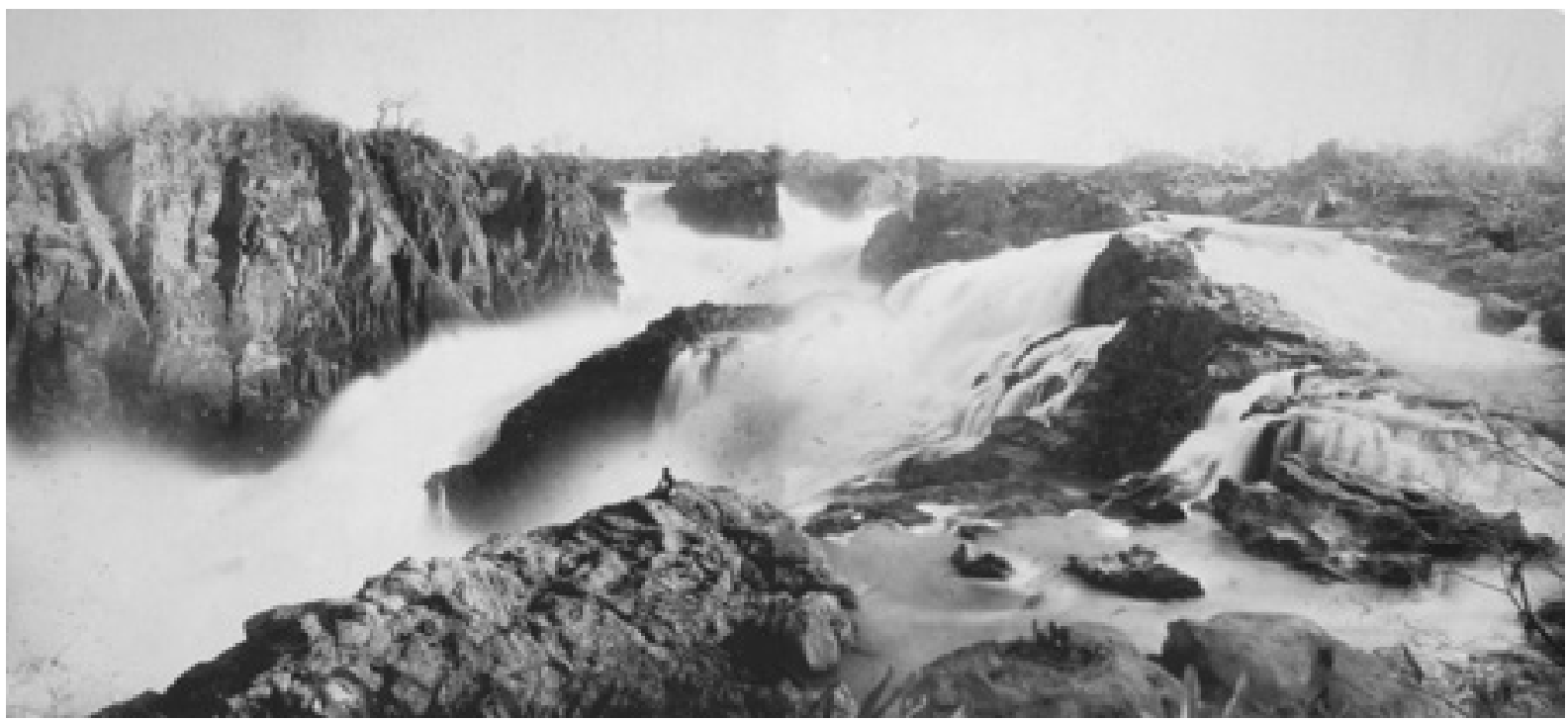

I

Figura I

Augusto Stahl. Cachoeira de Paulo Afonso, Rio São Francisco, Alagoas, I86-. Stahl \& Ca., Photographos de S. M. o Imperador do Brasil.

Papel albuminado, p\&b, $26 \times 56 \mathrm{~cm}$.

Acervo Fundação Biblioteca Nacional.

\section{Figura 2.}

Revert Henry Klumb. Tijuca/

La petite cascade, Rio de Janeiro, c. I860.

Albúmen.

Acervo Fundação Biblioteca Nacional.

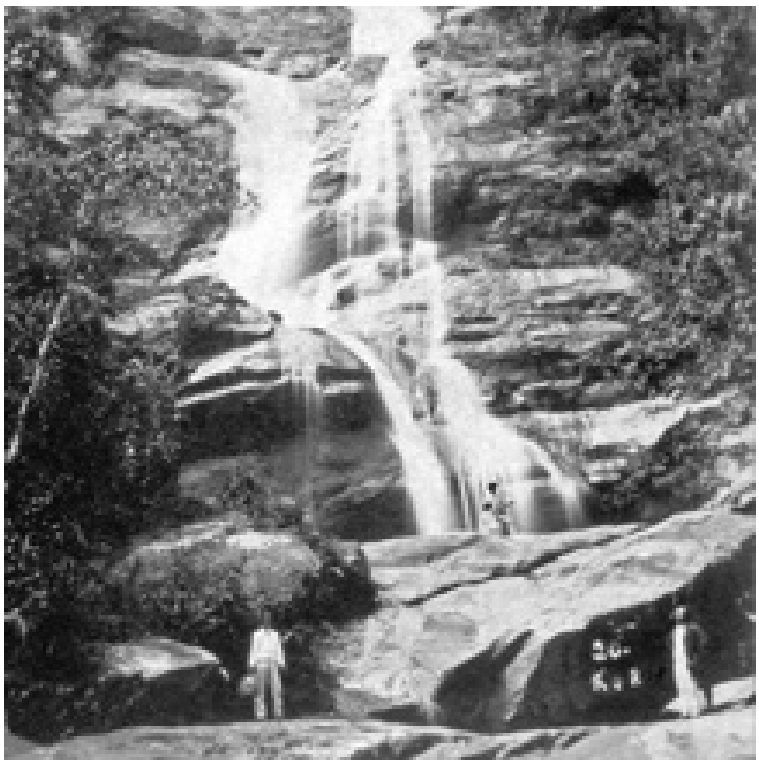

2 
Pátria é, pois, um sentimento atrelado à observação da natureza, logo convertida em um espetáculo, praticamente humano porque desvendada pelo sentimento humano.

A paisagem evoca, pois, uma política de afetos, um mundo das sensibilidades, e se no Brasil não tínhamos catedrais, palácios e toda a monumentalidade da Antiguidade, a natureza pujante dos trópicos bem que podia assumir esse mesmo papel. Imensa, diversa, exótica, ela cumpria as vezes da nação. Já os escravos figuravam nessas fotos como meros acidentes, como sinais, indícios humanos apequenados diante do esplendor do espetáculo. Por vezes, alguns desses "rapazes", como eram chamados os escravos adolescentes, buscavam uma pose que lhes conferia mais individualidade, como no caso do menino que, muito diminuto, sugere uma postura de maior desenvoltura corporal. Entretanto, se nesses exemplos eles não passam de detalhes, de toda maneira a constante presença de cativos como "marcos visuais" mostra, também sob esse ângulo, como era reiterada a tentativa de transformá-los em tipos ou personagens sem identidade. Definitivamente, nesse grandioso teatro do Estado, eles não atuavam como parte integrante da representação.

\section{TÃO BONS SELVAGENS}

E enquanto no país o retrato da natureza exuberante se colou à nossa própria identidade, e de alguma maneira a constituiu, também os nativos locais integraram esse imenso retrato coletivo, que ia sendo sonhado, escrito, desenhado e cada vez mais fotografado, contando com o mecenato da própria Coroa. Indígenas estariam presentes nas grandes telas de Amoedo (como 0 último Tamoyo, I883), de José Maria de Medeiros (com Iracema, I88I), e de Meirelles, com telas como Moema e A primeira missa (I860). Nelas, os indígenas seriam flagrados de maneira consoante aos modelos literatos de época: como aqueles que se sacrificariam para que a nação vingasse. Os naturais da terra seriam representados ora de maneira pacífica e idealizada (coerente com a literatura romântica de época), ora como mortos ou que viriam a morrer. Nada podem diante da civilização e a fotografia cumpriria um papel salvacionista, no sentido de preservar a imagem e evitar o total esquecimento (já que a desaparição era considerada como inevitável).

Nada lembra conflito, tensão, resistência ou contrariedade. No entanto, se os indígenas das telas acadêmicas teriam ficado presos no tempo e no passado, a fotografia atualizaria esse mesmo tipo de representação. Por isso, se a paisagem aparece embrulhada para presente, também os nativos surgem totalmente enquadrados pelas lentes e vestidos a caráter: exóticos, estão prontos para a admiração geral e para uma cena que não lhes compete.

Assim, se, como vimos, os africanos não fariam parte do discurso visual nacional, já os indígenas - devidamente idealizados - apareceriam ple- 
namente inseridos nessa espécie de cartografia simbólica de tipos humanos, e seriam prontamente convertidos em espetáculo da nação. Tão grandes quanto a paisagem, muitas vezes eles têm seus corpos propositadamente elevados, a partir dos novos recursos técnicos do fotógrafo. Esse é o caso da foto de Frisch, que literalmente colou índios Umauás ao documento original, que apenas retratava a paisagem amazônica. ${ }^{4}$

Imensos, eles são quase "bons selvagens" em seu habitat natural. O subterfúgio passaria como um objeto "verista", caso ficássemos apenas retidos à paisagem ao fundo. Já a dupla de guerreiros é claramente artificial e teria sido capturada pelas lentes de Frisch, quem sabe, no próprio ateliê. Na condição de personagens nativos - índios Umauás - eles guardam e respeitam as convenções necessárias: paramentados e vestidos como devem estar, portando os instrumentos que lhes condicionam e delimitam a identidade, eles não encaram as lentes, não são identificados por nomes, apenas posam passivamente. Tudo muito natural, não fosse a evidente desproporção que o fotógrafo não conseguiu evitar.

Mas, se no exemplo da Figura 3, o fundo decalcado lembra as selvas, em inúmeras fotos o ambiente é dado pelo ateliê improvisado, que deixa tudo ainda mais artificial. Sobretudo Marc Ferrez, um esteta da fotografia e dos tipos exóticos, faz um verdadeiro esforço no sentido de montar "nativos universais" (Sahlins, I997a, I997b), que carregariam um pouco de tudo que a curiosidade dos clientes poderia desejar: cocares imensos, lanças apontadas, indumentárias com plumárias e, de quebra, uma pele (que mais parece africana) ao fundo, para melhor ambientar e emocionar.

Indígenas personificavam, no contexto de finais do XIX, a representação da "infância da humanidade", ou, ainda, a imagem de um certo exotismo em vias de desaparecimento. Por isso mesmo, seriam convertidos por fotógrafos, como Marc Ferrez, em "tipos", e assim ainda mais caricaturados. No exemplo da Figura 4, fica evidente o artificialismo da operação com o retratado parecendo desengonçado e até embaraçado na função que se preparava para representar. Um cocar imenso e instrumentos de guerra completam um cenário em tudo irreal.

O mesmo Ferrez - o único fotógrafo radicado no Brasil a contar com um ateliê que se autossustentava, dado o sucesso da empreitada e por conta da proximidade que cultivou com a Coroa - se esmerou em conferir exotismo às fotos de indígenas que realizou. Em seu estúdio, vestiu um pequeno indígena com todos os adornos que sua condição (prévia) fazia jus: adereços nos braços, pernas e cabeça; tanga de penas, colar e cinturão. No entanto, a situação é tão imaginária que o fotógrafo parece não ter se contentado, e acabou por completar o cenário com pedras (devidamente recortadas) e até uma onça sobre a qual o jovem nativo apoia um dos pés, em gesto orgulhoso. Complementa a pose a mão esquerda à cintura e o olhar firme. O fundo é indefinido, 


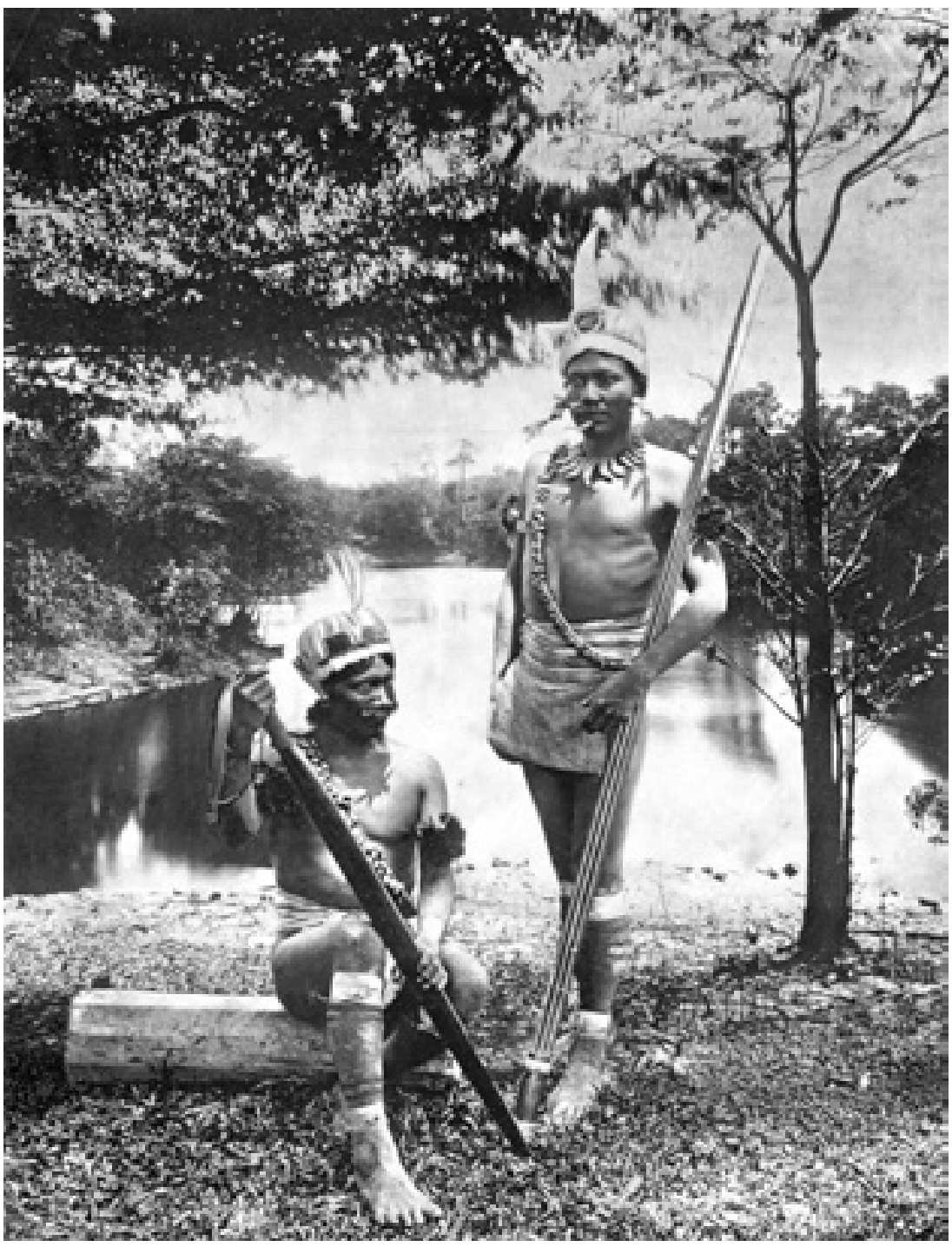

3

Figura 3.

Albert Frisch. Índios Umauá na antiga

Província do Alto Amazonas, região do rio

Solimões, Província do Alto Amazonas (atual

região do rio Solimões), Amazonas, c. I867.

Albúmen, 23,8 x I8,3 cm, fotomontagem.

Convênio Instituto Moreira Salles/

Leibniz-Institut für Laenderkunder. ${ }^{5}$ 


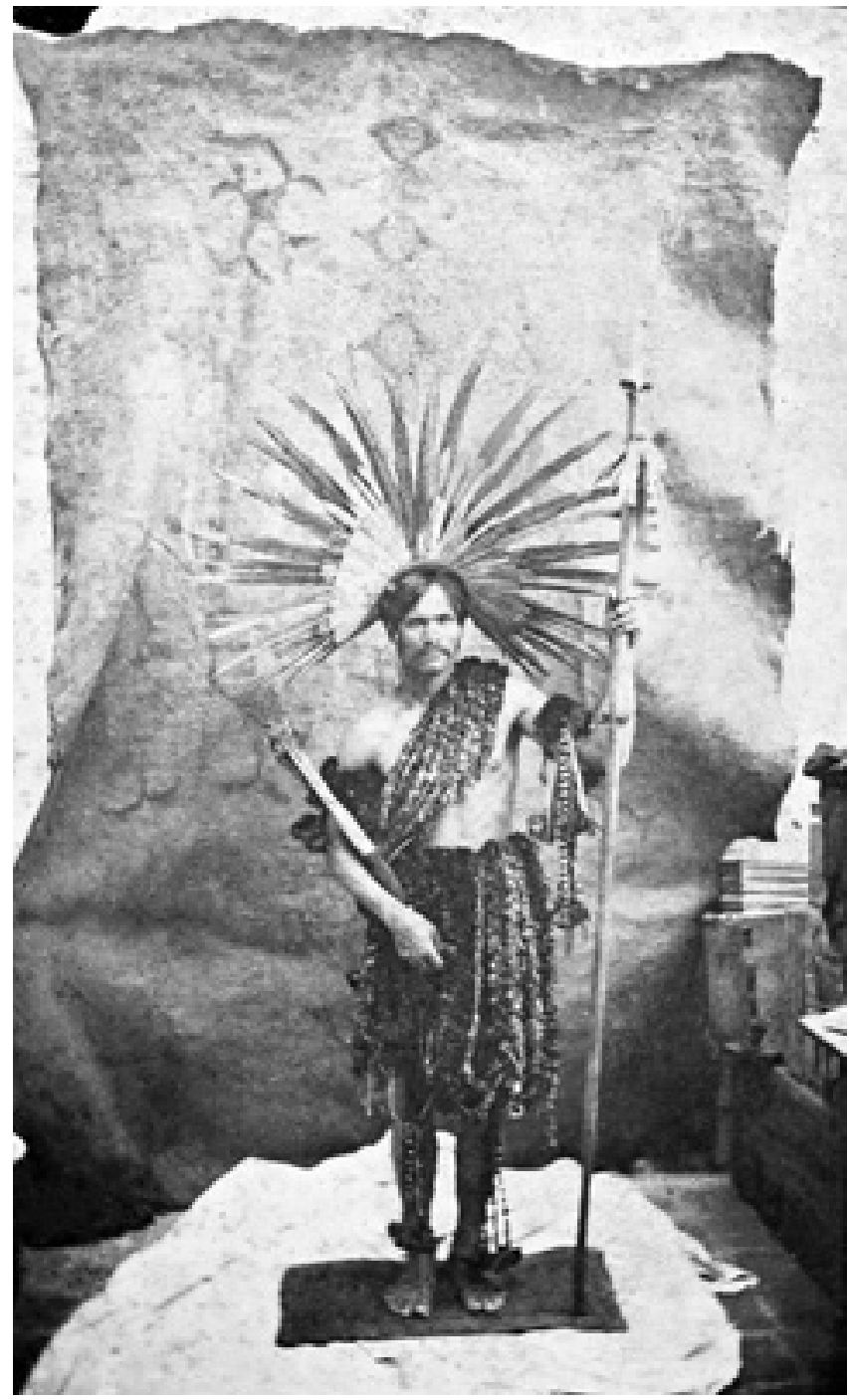

4

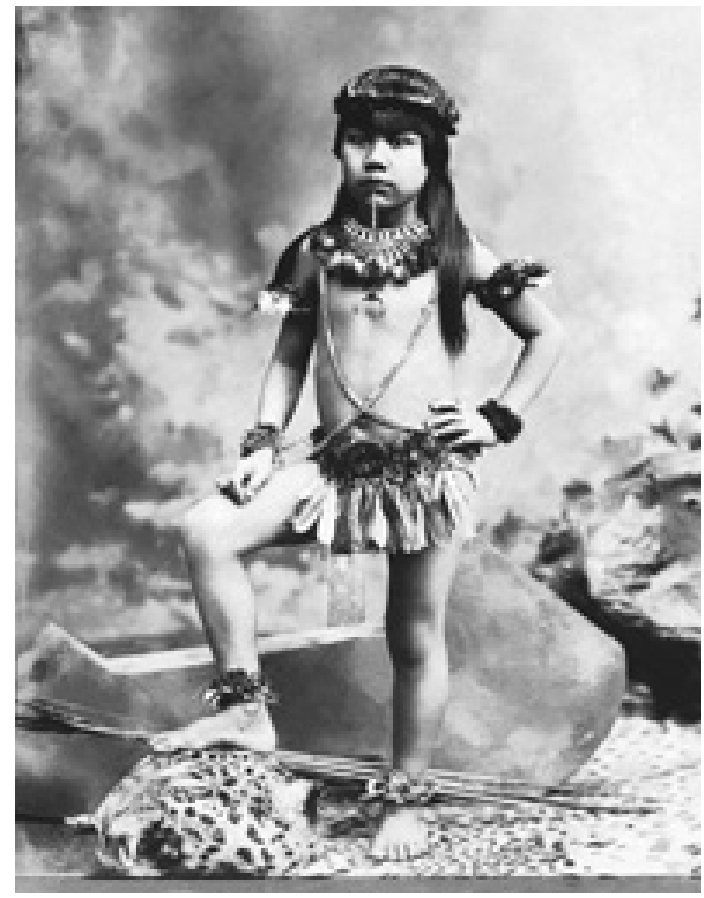

Figura 4.

Marc Ferrez. Chefe da tribo de índios

Appiacaz, no Amazonas, Amazonas, 1887.

Albúmen, I5,5 x 2I cm.

Acervo Museu Imperial/Ibram/MinC/n43/20I4.

Figura 5.

Marc Ferrez. Jovem índio do Mato Grosso,

c. I880.

Albúmen, 23,9 × 17,9 cm.

Acervo Instituto Moreira Salles. 
quem sabe contemplado com algumas folhagens que bem lembrariam os trópicos brasileiros.

O fato é que nessas imagens temos uma espécie de "resumo", uma súmula condensada, do que de antemão já se esperava ver: a barbárie (onde quer que ela estivesse situada), o bom selvagem, o tipo exótico no mal escondido arranjo estético do ateliê. Mas há outra foto ainda mais icônica. Nela, o artista Ferrez imortaliza (e "pacifica") os terríveis Bororos. Nesse contexto, esse grupo representava o modelo da "selvageria" e da insubmissão - "os índios da ciência" e que deveriam, portanto, ser dizimados. Eles seriam em tudo opostos aos Tupis - os índios do romantismo -, considerados como os verdadeiros "bons selvagens" (Cunha, 2000). Nesse caso, porém, o retrato é outro. Em meio a colunas neoclássicas do ateliê, vestidos de maneira provisória, eles posam também desajeitados.

As vestes e adereços que trazem não disfarçam a situação artificial que vivenciam. O casaco jogado sobre o corpo desnudo do personagem central sentado (provavelmente o cacique) contribui para a caricatura da situação. O fundo descuidado documenta o improviso deste registro, a começar pela coluna à esquerda, que mais parece lembrar um encontro imaginário dos nativos com a cultura clássica. A vegetação é ainda mais arremedada, parece pobre e seca, como se fosse preciso sempre ladear esses figurantes com elementos que lembrassem a floresta e remetessem à sua origem remota. Enquanto as elites brancas escolhiam diferentes fundos falsos para compor suas fotos - um teatro europeu, um chalé suíço, um parque na França, uma paisagem urbana -, já os nativos pareciam merecer um "cenário cativo": uma imagem que desse conta e definisse sua condição.

A fotografia de postais parece ter assumido uma espécie de missão social: a de apresentar fantasmas coletivos sob a forma de imagens e inaugurar um verdadeiro voyeurismo da sociedade imperial. Mistificação e êxtase, uma nostalgia do "primitivo" perdido parece fazer parte dessa representação de uma ferida dolorida que se revela sob a forma de um "fantasma degradante" presente na "realidade fotográfica". Esse é o butim da visada ocidental, do consumidor da fantasia de luxo e dessa estetização na natureza e de seus naturais (ver Alloula, I986). Espécie de projeto antiestético, aqui se confronta uma imagem que no fundo não é mais bela, é o empobrecido, o efêmero: o que vai desaparecer. Trata-se quase do "retorno do reprimido" sob a forma dessa visualidade imperial, esse sentimento de exílio e de impotência. Apesar de naturalizadas, elas representam um confronto violento e forçoso entre texto e imagem. Imagem transformada em texto e discurso (Said, I986). Por isso, essas fotos também parecem perder contexto, nome ou identificação: perdem o tempo para virar alegoria.

Utilizando recursos diversos, natureza e nativos estavam sempre vinculados nesse projeto do Estado imperial que convertia seus súditos em ex- 


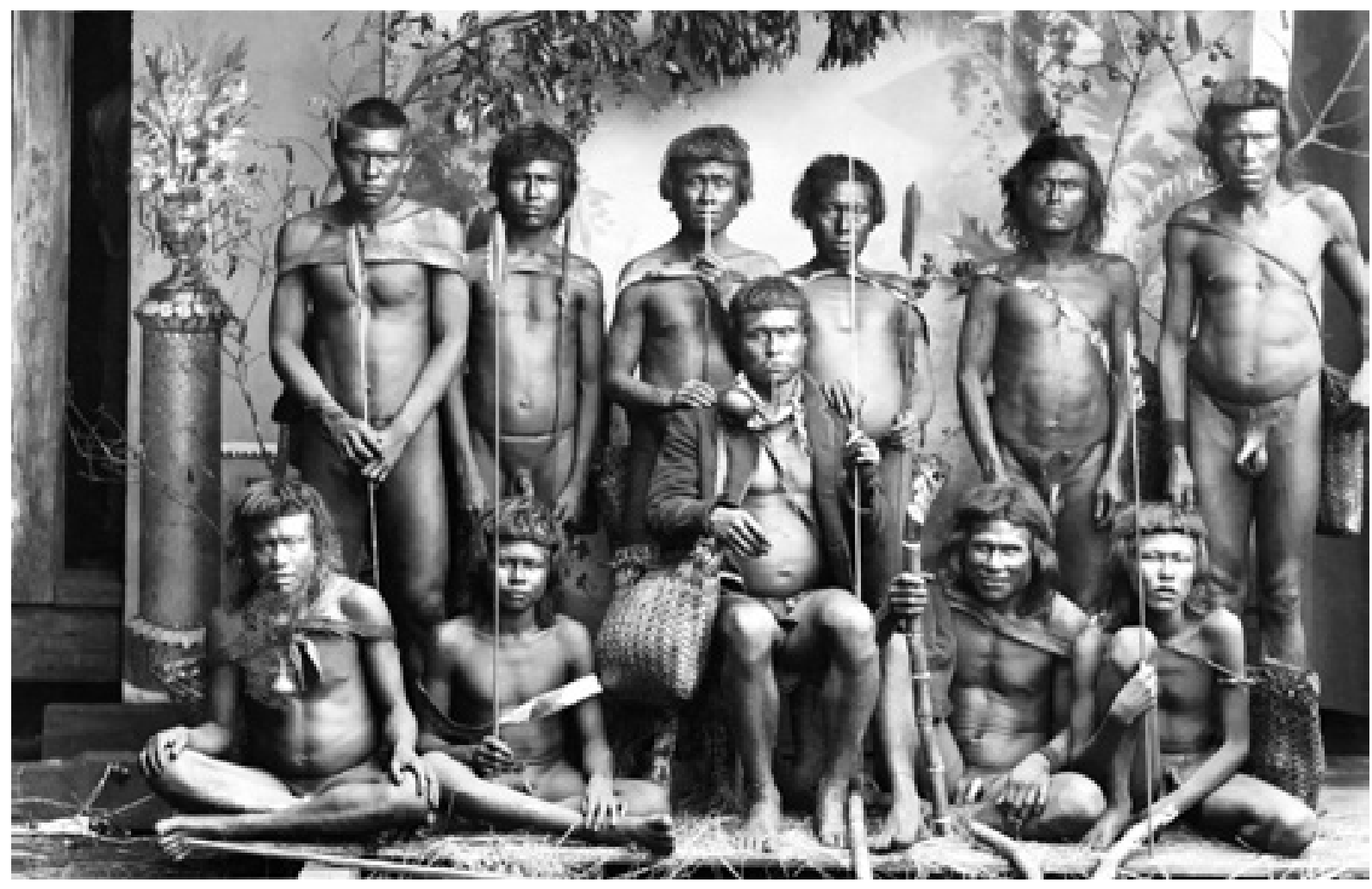

6

Figura 6.

Marc Ferrez. Índios Bororo, Goiás, c. I88o.

Albúmen, 2I,2 x 25,8 cm.

Coleção Gilberto Ferrez.

Acervo Instituto Moreira Salles. 
cêntricos, na mesma medida em que projetava o Império como a mais particular, mas também a mais universal das monarquias. E para tanto, falta um pedaço desse quebra-cabeça: o próprio soberano.

\section{CARA OU COROA: A MONARQUIA E A FOTOGRAFIA}

Resta agora mencionar o maestro dessa orquestra. Não há concerto sem harmonia e essa é dada por seu condutor. E, como vimos, D. Pedro não só assumiria a função de mecenas das artes, financiando artistas e animando a entrada da fotografia no Brasil, como, em algumas ocasiões, participaria como solista nesse grande concerto: por vezes era maestro, por vezes virtuoso, por vezes musa inspiradora. Afinal, o monarca não só colaborou com a entrada da fotografia no país, como ele próprio foi fotógrafo e se fez fotografar. D. Pedro se reinventaria dessa maneira, assim como incentivaria a vinda de muitos profissionais do ramo.

O monarca costumava inclusive afirmar, no Brasil e no exterior, que se as demais monarquias preferiam imortalizar sua imagem oficial a partir de retratos a óleo - por conta da durabilidade da pintura e dos formatos amplos e generosos das pinturas acadêmicas -, já ele aderiria ao novo invento: a fotografia, a qual, de alguma forma, converteu-se em sinônimo dessa era ligeira e dada a todo tipo de modernidade. Por isso, a história da fotografia no Brasil permaneceria por muito tempo atrelada à monarquia, da mesma maneira que a Família Imperial converteu-se em objeto dileto dos retratos desses profissionais. Muitos deles eram tão ligados a ela que conseguiam ampliar sua clientela a partir dos vínculos que estreitavam com o soberano. Daguerreótipos, cartes de visite, ${ }^{6}$ fotos, estereoscopias... todo suporte servia para multiplicar a presença da monarquia por todo o território. ${ }^{7}$

Muitos foram os retratos feitos da família imperial, e, sobretudo, de Pedro II. ${ }^{8}$ Em geral sereno, porte altivo, seguro, o monarca é a própria representação da nação. Nas inúmeras fotos, litos e litogravuras aquareladas do soberano, destaca-se a pose cuidadosamente talhada, o ar impoluto, sério, altivo: dissimulado. Seu papel predileto era o de mecenas ilustrado, cercado de livros, globos e demais símbolos de erudição. Como se vê logo na sequência, de jaquetão, botina, pernas cruzadas e livros por todos os lados, Pedro II buscava fazer desse tipo de imagem sua própria definição, assim como se moldava a partir dela e do desejo de seus súditos. Nas fotos o rei é agora a projeção desse Estado que buscava veicular uma imagem civilizada, contrária às demais repúblicas latino-americanas, e sempre afastada da sombra da escravidão.

Barba cada vez mais espessa, olhar compenetrado, criador e criatura representavam um país de difícil anotação. Não há como perseguir aqui todas as imagens que ajudaram a construir o rei, como rei. Mas o que mais importa destacar é como ficava cada vez mais difícil discernir o monarca de sua pro- 


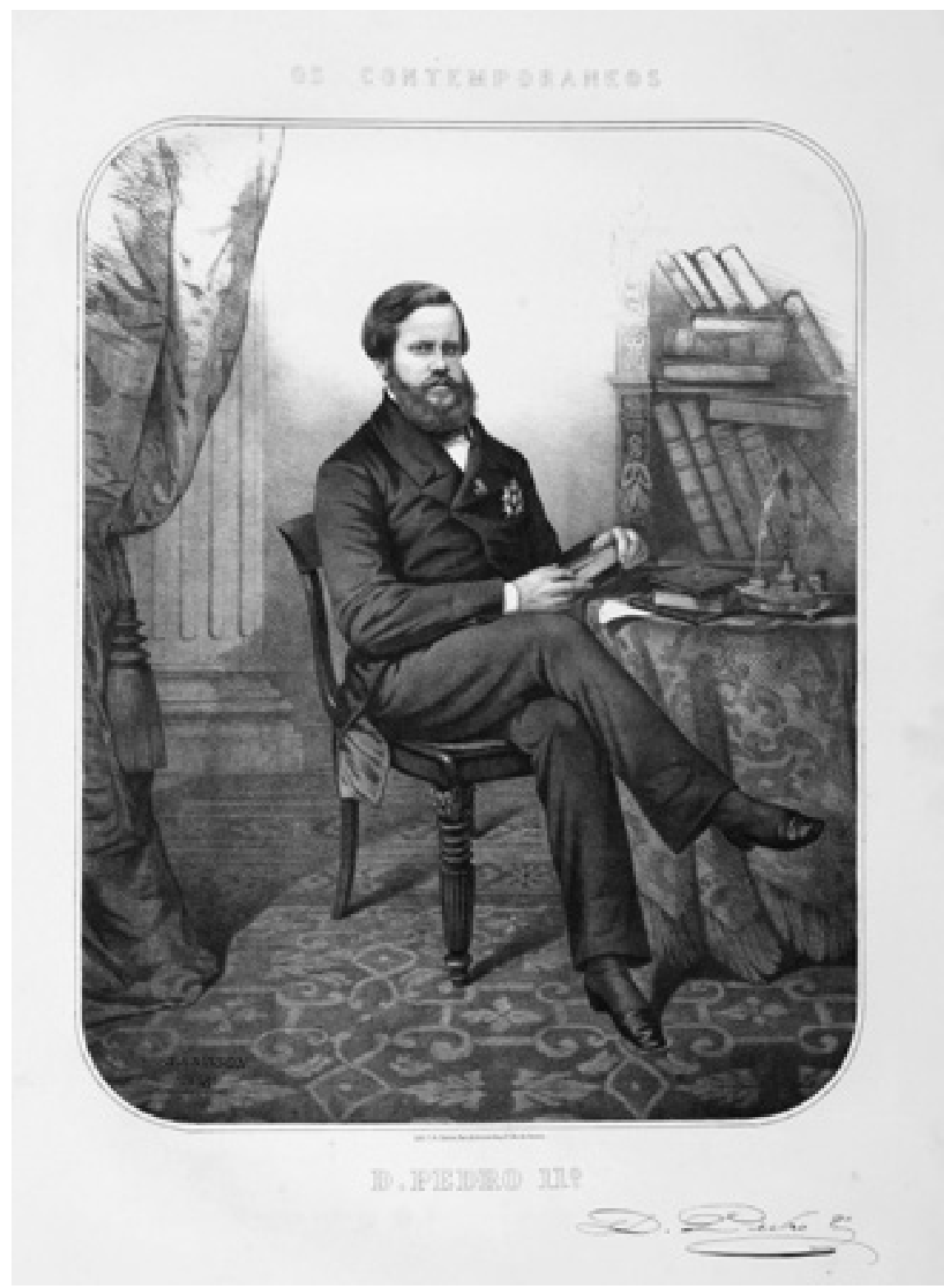

7

Figura 7.

Sebastien Auguste Sisson. D. Pedro II, Rio de Janeiro, I86I. Litografia baseada em foto. In: "Galeria dos Brasileiros Ilustres" ("os contemporâneos", vol. I).

Biblioteca Brasiliana Guita e José Mindlin - USP. 
jeção iconográfica. Na verdade, ele correspondia à ponta mais destacada de um "triângulo nacional", em que apareciam irmanados a natureza e seus naturais - os trópicos e "suas gentes" - nossa sublime diferença -, mas também os próprios soberanos e seus descendentes. Afinal, causavam curiosidade não só os indígenas e a escravidão, como essa monarquia "cercada de repúblicas por todos os lados" e governada por um descendente de Bourbon, Habsburgo e Bragança. ${ }^{9}$

Com seu apoio, o imperador acabou por conferir à fotografia a legitimidade que ela carecia. Talvez por isso, a fotografia virou uma febre entre as elites brasileiras, servindo como marca e símbolo de status (ver Mauad, I997; Kossoy, I980; Brizuela, 20I2; Vasquez, 200I, 2003). O fato é que D. Pedro II não seria apenas o modelo oficial das fotos oficiais, como se daria ao luxo de brincar com a técnica. Por vezes duplicado, sentado em seu gabinete, ele mais parecia representar o modelo "do corpo duplo do rei", e assim virava cada vez mais uma projeção de seu Estado.

Nessas fotos, o casal imperial posa para fotógrafos oficiais da Corte, e os mesmos mostram, com seus próprios corpos, os artifícios da técnica. Mas qual a graça da imagem duplicada? Com certeza, alguma piada havia em tal encenação. Quem sabe, nesse caso, o excesso deva ter funcionado como alusão, e D. Pedro ria da própria proliferação de sua imagem; didaticamente duplicada. Nessa época, era comum encontrar uma foto de D. Pedro nas repartições, teatros e palácios, em lojas, restaurantes e até nas paredes das casas. O imperador se convertia, assim, em amigo próximo, figura onipotente, já que sempre presente. Se ele não podia estar em todo o país, já sua imagem corria diferentes percursos e ocupava todos os espaços, por meios das gravuras, litos e fotos. Duplicar sua figura significava, quiçá, brincar com o espetáculo da divulgação da imagem própria. Por outro lado, como conhecido adepto das novas vogas, cabia também ao soberano aclarar os bastidores das fotografias e mostrar a artificialidade da operação. Se os demais clientes se nutriam do teatro e do ritual da fotografia - e se valiam dele como forma de afirmação social -,já o monarca, acima dos demais, brincava com ela. Mas há ainda outra possibilidade. Talvez as fotos duplicadas metaforicamente traduzam - em tempos modernos - a tradicional concepção do corpo duplo do rei: o real e o sagrado; aquele que morre como os demais homens e aquele que não morre jamais (Bloch, I980). Se nos fiarmos nesse argumento, a era da técnica seria responsável por reler e ressignificar o costume antigo, dando-lhe inusitada novidade. Mas não é preciso ir tão longe: as fotos foram tantas, e distribuídas de maneira tão eficiente, que D. Pedro ia sendo lembrado por sua representação em branco e preto e em formato cartes de visite (ver Schwarcz, 2000; Vasquez, I985). Com isso as imagens ganhavam o lugar de metáfora, mas também de efeito do real: dois ou muitos. 

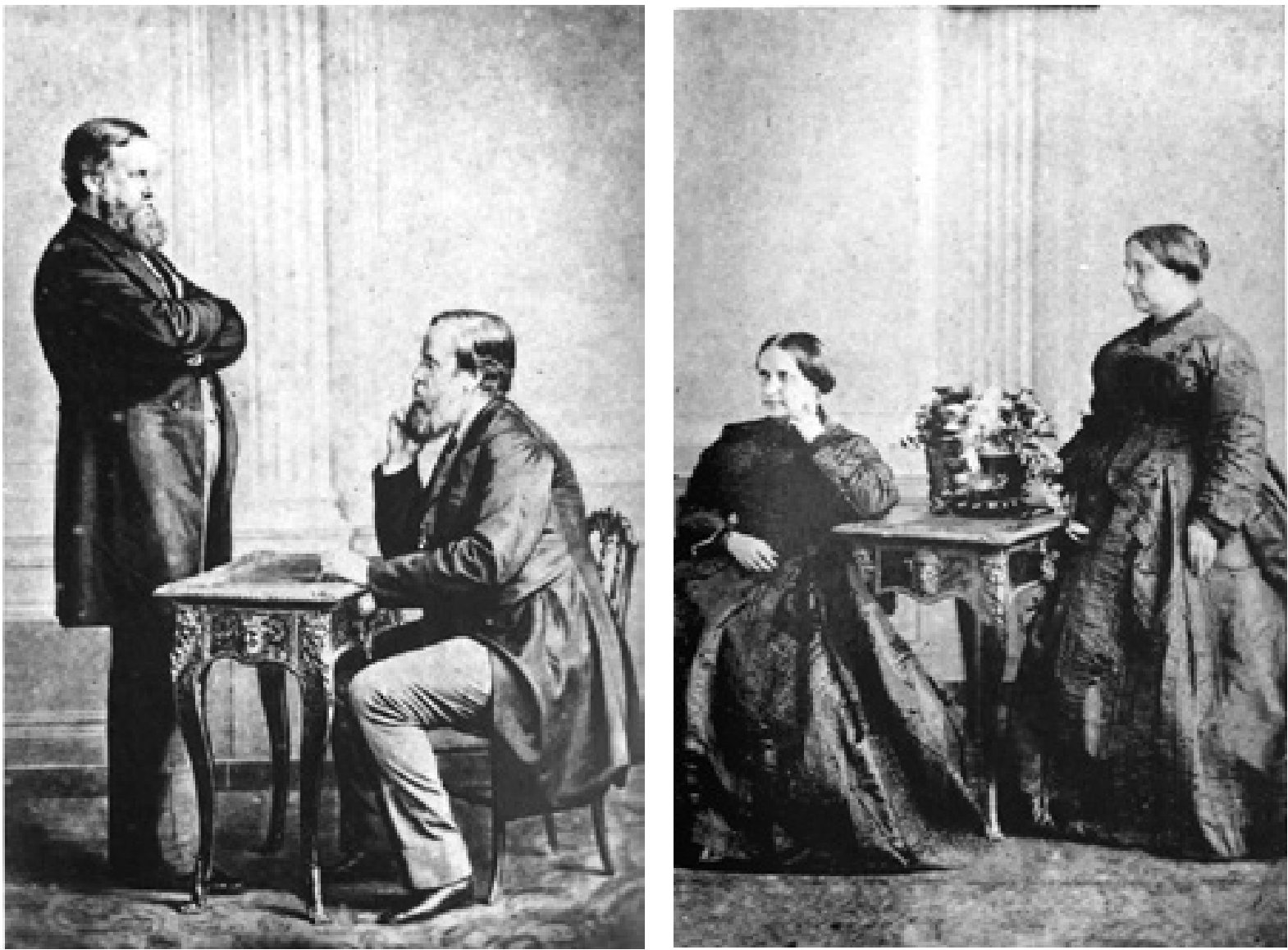

8

Figura 8.

Carneiro \& Gaspar. A Imperatriz Teresa

Cristina observando a si mesma e

D. Pedro II conversando consigo mesmo,

Rio de Janeiro, c.I867.

Albúmen, carte-de-visite, fotomontagem.

Acervo Arquivo Grão Pará. 
E as diferentes pontas desse triângulo comunicavam-se e se reforçavam reciprocamente. A estetização da natureza e da monarquia alcançou tal escala que Estado e trópicos começavam a se interpenetrar num mesmo projeto de elevação. Vale anotar uma falsa coincidência que incluiu quatro diferentes suportes artísticos - uma tela acadêmica, uma escultura de artista da Academia Imperial de Belas Artes, uma caricatura de Angelo Agostini e uma fotografia de Insley Pacheco - que se comportam como se fossem uma série iconográfica, que conversa entre si, e, por meio dela, conosco. ${ }^{\text {Io }}$ É em I872 que Pedro Américo completa uma das grandes telas do Império, retratando Pedro II na abertura dos trabalhos da Câmara.

Altura maior que os demais, barba ruiva, todo paramentado em sua realeza, Pedro II é imortalizado como um rei à frente do Congresso e tendo o trono, símbolo maior de seu poder, ao fundo tal qual uma grande sombra. No mesmo ano, Francisco Manuel Chaves apresentava a escultura (de gosto duvidoso e título preciso): "Índio representando a nação brasileira".

Nela, basicamente invertem-se elementos já presentes na tela de Américo. Na escultura, é um índio que ostenta os emblemas da monarquia, expressos pela coroa, o cetro, o manto e o porte elevado. E se não estivéssemos certos, o título ajudaria a dirimir suspeitas. Afinal, nele se explica (didaticamente) o papel que o indígena assumia na representação oficial, como se, em paralelo, tivesse a envergadura de um monarca entre seus súditos. Nesse caso, porém, é o soberano ocidental que está em evidência - mesmo de maneira metafórica, uma vez que são os símbolos desse Estado que aparecem nas mãos do nativo. É por isso que Angelo Agostini faz graça com caricatura coetânea, usando a piada como forma de inversão de expectativas (Darnton, I978; Geertz, I975). Nesse caso, é o indígena que ri do monarca, vestido tal qual a escultura de Francisco Manuel Chaves.

Ele ri das mazelas desse Estado, das retóricas românticas, e das crises que se aproximavam e eram cada vez mais percebidas pela opinião pública. Por fim, Insley Pacheco imortaliza o imperador Pedro II como um rei, definitivamente tropical, em seu estúdio. Olhar cansado, jaquetão, botas e um ateliê totalmente decorado com "ares americanos", a foto parecia colocar um ponto final nessa grande construção simbólica feita aos pedaços.

Se de um lado impressiona o olhar melancólico, um pouco fatigado, do soberano, ao mesmo tempo salta aos olhos o fato de ele escolher como cenário um ambiente com palmeiras e muitas plantas exóticas. Tudo contrastado com suas barbas cada vez mais espessas e brancas. Ao fundo Insley Pacheco deixou escapar uma paisagem mais amena, temperada até, quem sabe mais ao gosto do restante da clientela, a qual, com toda certeza, haveria de preferir ser clicada num ambiente mais europeu e menos excêntrico. Já nosso monarca opta pelos trópicos quase selvagens, como se esses definissem a especificidade desse reinado, sua grande e seleta identidade. Chama igualmente a 


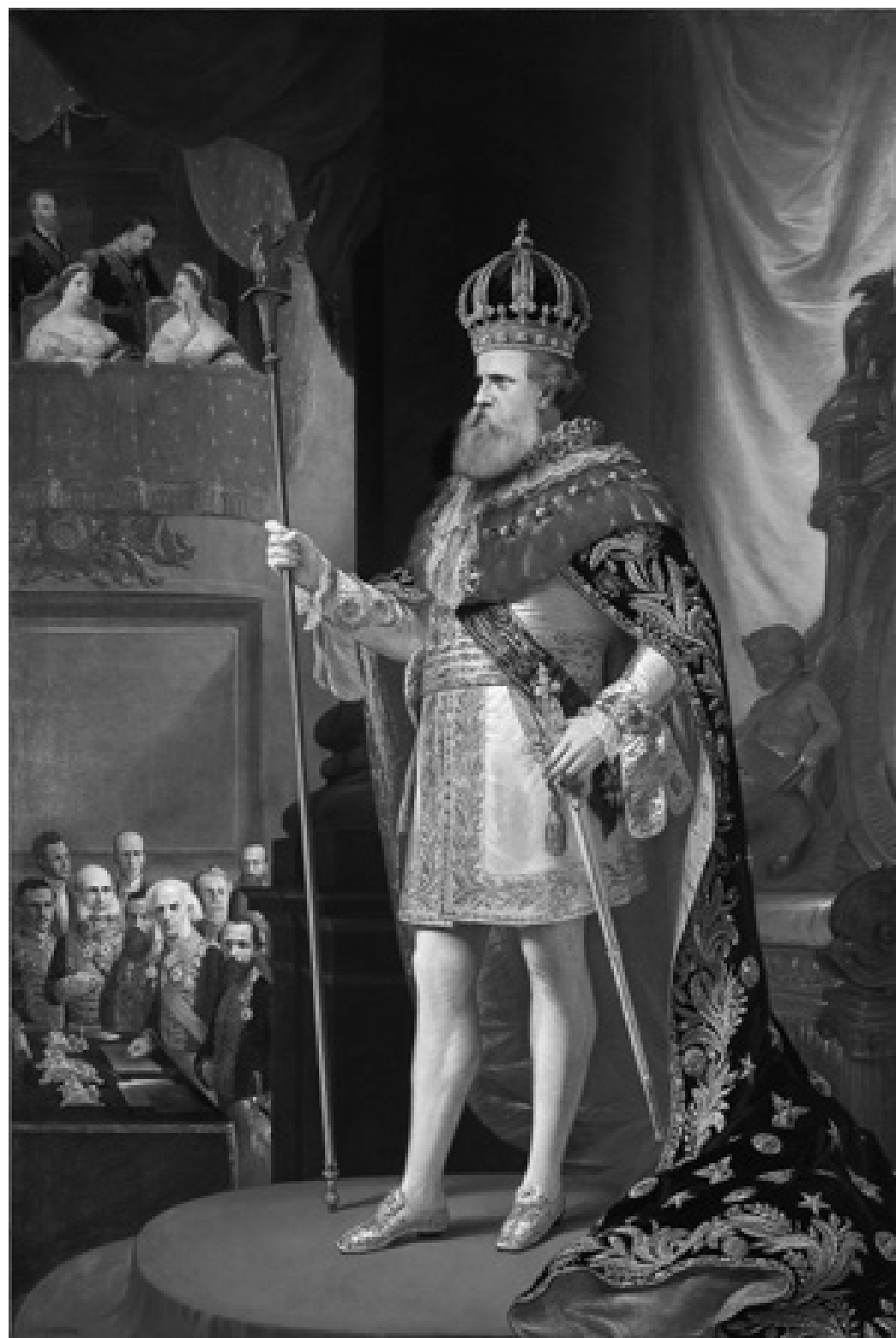

9

Figura 9.

Pedro Américo de Figueiredo e Mello.

Pedro II na Abertura da Assembleia Geral, I872.

Óleo sobre tela, $288 \mathrm{~cm} \mathrm{X} 205 \mathrm{~cm}$.

Acervo Museu Imperial/Ibram/MinC /n43/20I4. 


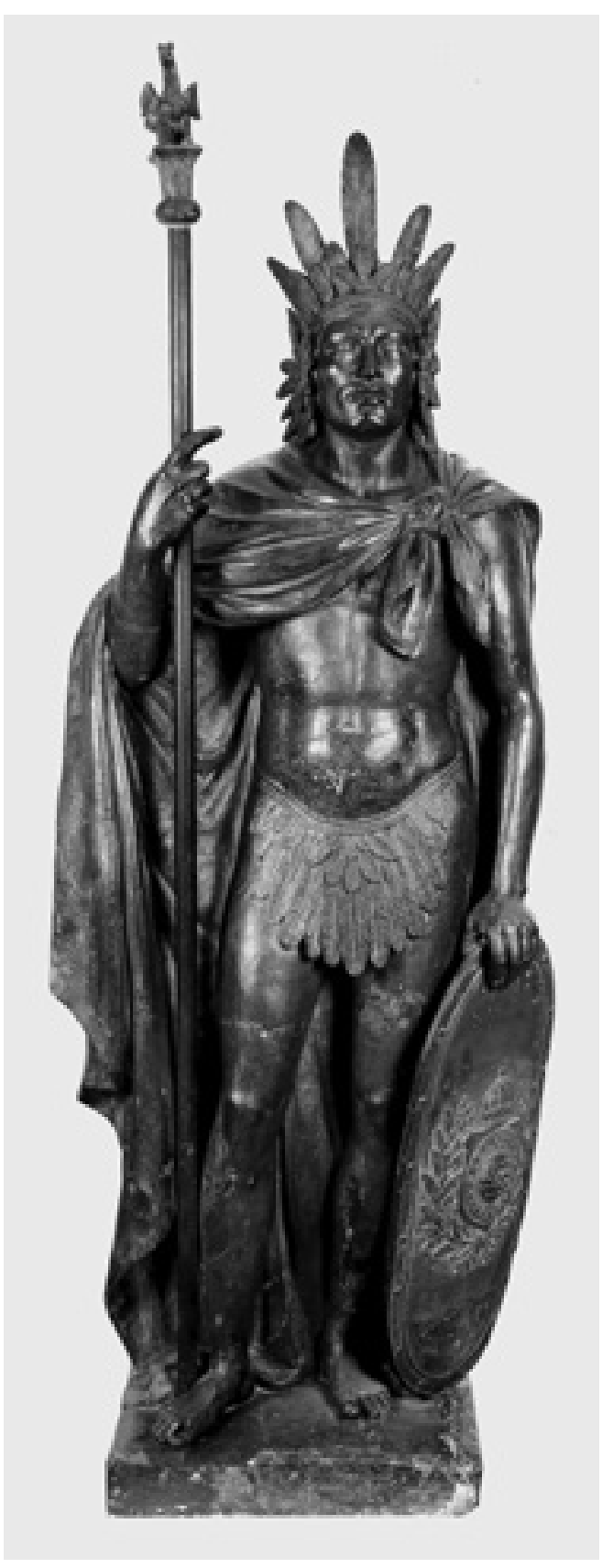

IO

Figura Io.

Francisco Manuel Chaves Pinheiro.

Alegoria do Império Brasileiro, 1872.

Terracota modelada, $192 \times 75$ x 3I cm.

Fotografia: Jaime Acioli.

Coleção Museu Nacional de Belas Artes/

IBRAM $/ \mathrm{MinC} / \mathrm{n}^{\circ} 25 / 2014$. 


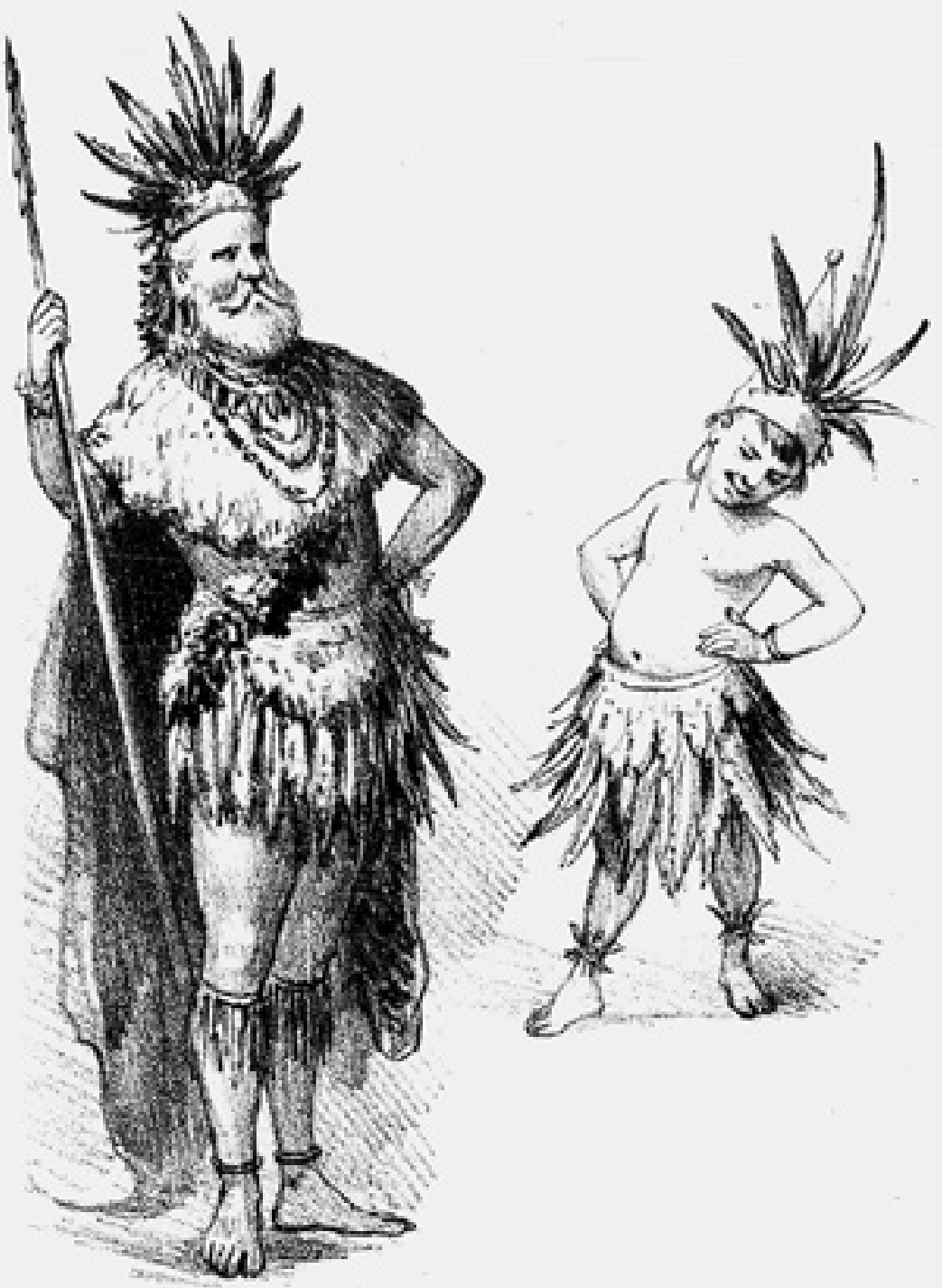

Figura II.

Angelo Agostini. Caricatura de D. Pedro II.

Revista Ilustrada, nº 310 , I882.

Acervo Fundação Biblioteca Nacional. 
atenção outro detalhe, só descoberto por um olhar mais afiado ou quando ampliamos a foto. Em primeiro lugar, o imperador encontra-se sentado numa daquelas rochas improvisadas nos estúdios. Com isso, o fotógrafo já buscava imobilizar o movimento e garantir que a foto chegasse a um bom resultado. Entretanto, se uma das mãos encontra-se pousada nos joelhos, já a outra apoia-se num livro, outro símbolo constantemente utilizado pelo monarca em suas fotos oficiais. Assim, natureza e erudição; paisagem e cultura; os trópicos e a civilização compunham essa foto que mais parece com um autorretrato do Estado e de sua nacionalidade. O projeto nacional de exaltação da natureza é, assim, marcante neste retrato do imperador, como se pode notar a partir do esforço de "implantar" a paisagem no interior do ateliê: representação teatral perfeita de uma civilização nos trópicos.

A essas alturas, e quanto mais chegamos ao ocaso do Império, a representação oficial se parecia com uma re-apresentação. O imperador, para além dos truques fotográficos, virava um duplo de seu Estado: parte da paisagem, da natureza e de seus naturais. Na última feira universal que o Império participou - a de I888, em Paris -, enquanto as demais monarquias fizeram greve e se negaram a tomar parte do certame, uma vez que ele era organizado como uma homenagem ao centenário da Revolução Francesa, já Pedro II e seu estafe decidiram não apenas aderir, como construir um belo estande. Nele estavam expostos os produtos naturais do Império, alguns objetos indígenas e um belo lago com vitórias-régias. Para completar a cena, o próprio Imperador deixou-se por lá ficar, bem na frente do pavilhão, para a apreciação geral do público. No seu diário deixou comentário memorável e bem a seu gosto: "Dessa vez fizemos bonito!" Mas ao que tudo indica, nesse caso, ele errou em cheio. Esse seria o derradeiro teatro de sua imagem. Ele próprio virara sujeito, objeto e representação de seu reino tropical. Dizem que saiu contente com seu feito e com seu Império. Mal sabia ele que em um ano não seria mais rei e que o Brasil teria uma república.

\section{O OUTRO LADO DO ESPELHO É O OUTRO LADO}

Mas nem sempre as fotos podem ser controladas de forma absoluta. Tanto que muitas vezes fotografias de rua parecem menos reais do que as de estúdio e o contrário é igualmente verdadeiro. Além do mais, há sempre agência em meio à convenção. Hora de observar um tema que parecia escapar da agenda oficial do Império, mas retornava feito visita pouco esperada. Reparemos nessa cena, envolvendo a tópica das liteiras. Isto é, à época, vários gravuristas, e depois fotógrafos, flagraram membros da elite sendo transportados em liteiras, de tal maneira que uma imagem parecia conversar com outra, criando uma verdadeira convenção. Já a foto que selecionamos é tomada num estúdio, e poderia muito bem ser 


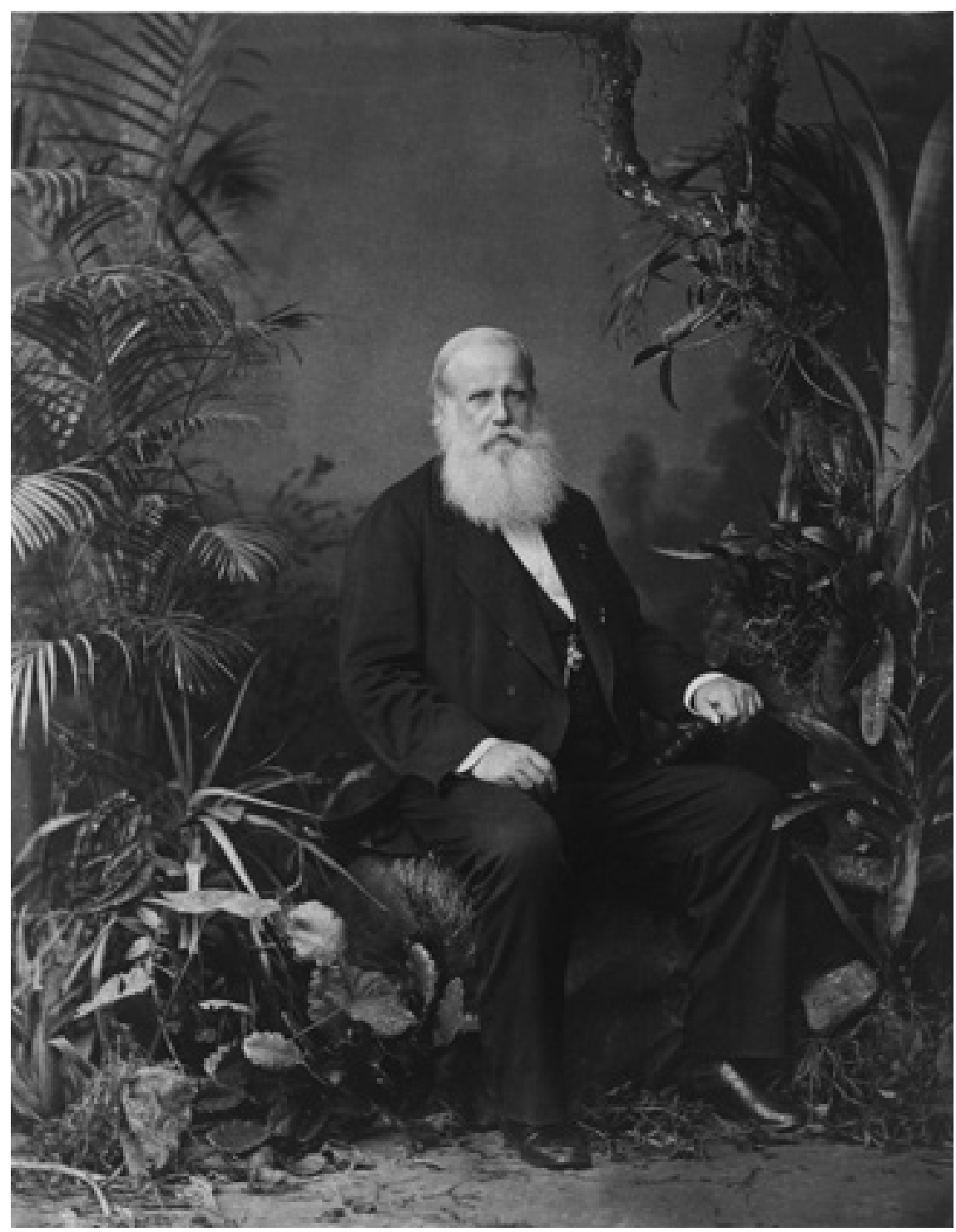

I 2

Figura I2.

Joaquim Insley Pacheco. Pedro II,

Imperador do Brasil, Rio de Janeiro, I883.

Platinotipia, $37,5 \times 29,6 \mathrm{~cm}$.

Acervo Fundação Biblioteca Nacional. 
apresentada como mais uma versão dessa mesma estrutura: senhores em suas liteiras e no centro da foto; escravizados apenas a ladeá-los. No entanto, um detalhe acaba por inverter o topos e os jogos de convenção. Ao centro, está uma senhora muito bonita, bem vestida e portando joias que denotam sua posição social. É para ela que convergem as luzes e o foco da fotografia. Seu corpo também verga um pouco para a frente - em direção à câmara - o que mostra como ela é o objeto último da foto. Além disso, a corroborar a interpretação, está o título do albúmen: se ele não traz o nome da misteriosa senhora, ficamos sabendo ao menos de que família ela provém: dos influentes Costa Carvalho. Mas o jogo que se estabelece entre fotógrafo e fotografados faz das suas, e dessa vez "o objeto" que deveria ser quase transparente ou invisível deixa de se comportar como o previsto: um dos personagens secundários vira sujeito e literalmente rouba a cena. No caso do escravizado à esquerda há uma clara acomodação de papéis: descalço, mas bem vestido (revelando tratar-se de um cativo doméstico), ele curva seu corpo em direção à senhora, tira seu chapéu, e evita olhar para o fotógrafo ou até mesmo para a moça da foto: seus pés paralelos e olhos quase fechados procuram o chão do estúdio. Já o cativo do lado direito faz tudo "longe da curva". Ele encara o fotógrafo, mantém o chapéu na cabeça, mostrando desenvoltura e uma liberdade que contradita sua condição. Além do mais, cruza os braços, coloca a mão na cintura, não retira o seu chapéu e mira de frente o fotógrafo (e quiçá o senhor - o marido - que bem poderia estar ali sentado, bem à frente, contemplando "a sua" obra). Aí está um jogo de corpo que fala por si só, e interpela aos demais. Com a mão - insolentemente - à cintura e outra levemente apoiada na haste feita para carregar a liteira - como se descansasse e nada tivesse a ver com o trabalho - ele se vira diretamente para a câmara e faz uma pose que pouco denota serventia. Ao contrário, ele parece senhor de si. Há mais um paralelo importante a anotar: nem a senhora, nem seus escravos têm seus nomes revelados, como se marcadores sociais de diferença - raça e gênero - bastassem para caracterizar "quem é quem" no cenário. Mulheres, assim como escravos, eram considerados espécie de propriedade de suas casas, apesar de ocuparem hierarquias e lugares sociais em tudo distintos. De toda forma, há um anonimato presente no documento, assim como uma inversão de locais. Ao menos transitória.

Assim, se as imagens nunca "refletem", tão somente, o real, no caso da fotografia um novo elemento precisa ser destacado: a ingerência dos agentes que não se conformam, muitas vezes, em apenas cumprir com um script predeterminado. Como mostra Eduardo Cadava:

The relation between the represented object and its representation, between reference and image, does not presuppose an object whose being and existence precede, or remain outside, the process through which it becomes an image. On the contrary, Barthes suggests that photo-graphic representation stages - makes absolutely "literal" - what is at the heart of modern representation, and this is precisely the putting into crisis of a temporal order in which first there is an object and then later its representation. What stands in front of the photograph- 


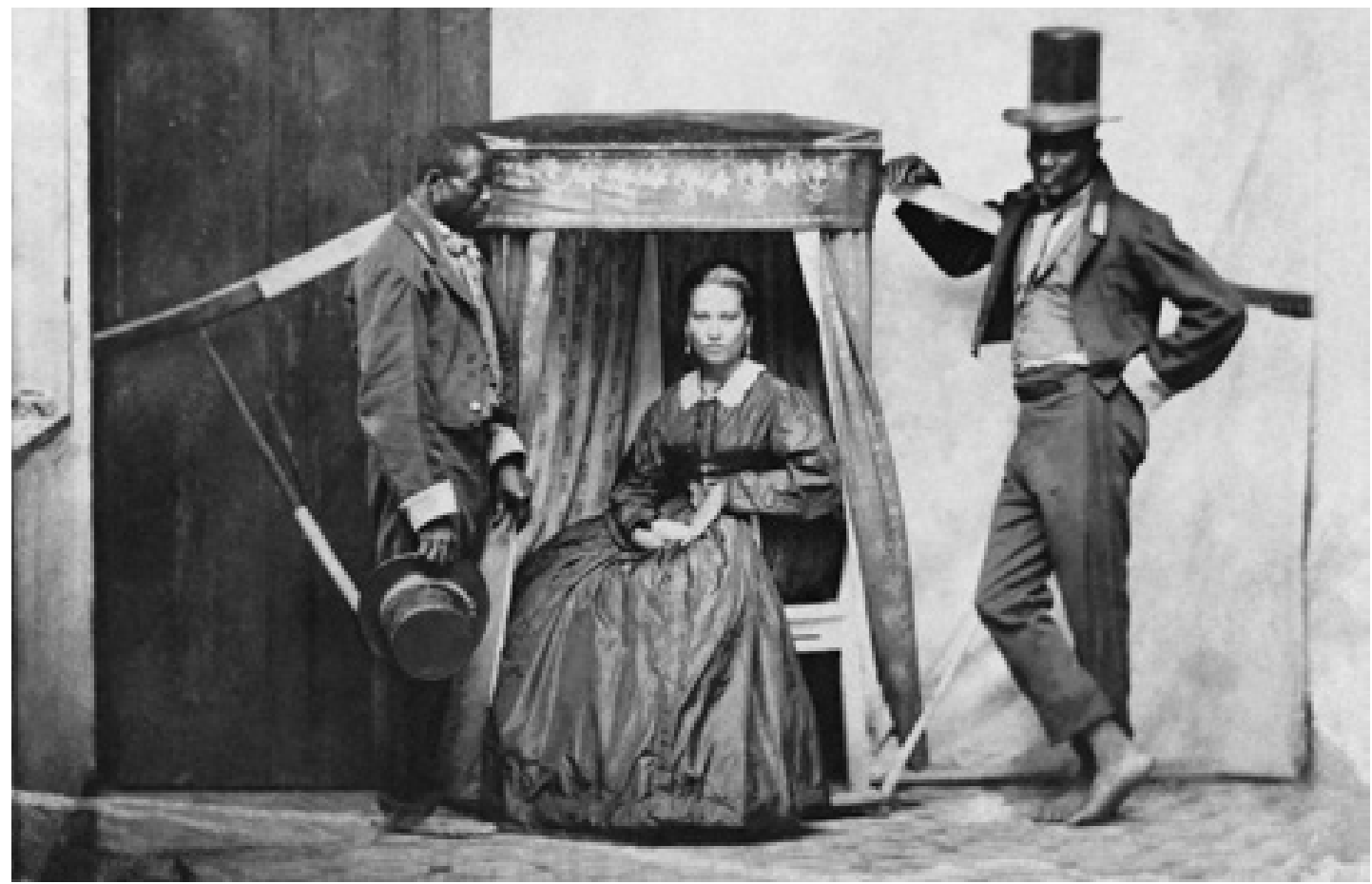

I3

Figura I3.

Fotógrafo não identificado. Senhora da família Costa Carvalho na liteira com dois escravos, Bahia, c. I860.

Albúmen, 5,5 × 8, $1 \mathrm{~cm}$.

Acervo Instituto Moreira Salles. 
ic apparatus - an object or subject that gives way to a portrait - does not "exist" before the camera's click. As Barthes explains, "once I feel myself observed by the lens, everything changes: I constitute myself in the process of 'posing', I instantaneously make another body for myself, I transform myself in advance into an image" (CL, p. 10/CC, p. 25). This "active" transformation is not that of someone who offers himself to the camera, like some sacrificial victim, in order to be reproduced, but rather that of someone who knows that what makes him what he "is" - and therefore prevents him from ever being simply "himself" - is the multiplicity that inhabits "him" [...] In front of the lens, I am at the same time: the one I think I am, the one I want others to think I am, the one the photographer thinks I am, and the one he makes use of to exhibit his art. In other words, a strange action (Cadava \& Cortés-Rocca, 2006: 36).

À frente das lentes todos podem virar "outros" e criar novas realidades para si e para os demais: uma impostura tão calculada como por vezes inesperada. Tudo parece estar pronto - os papéis previamente estabelecidos e os locais demarcados -, mas pequenas ou grandes agências podem alterar significativamente o resultado final. Aí estão imprevistos do ofício que mesmo que sem a intenção, acabaram por flagrar escravos nas mais diferentes situações: de coadjuvantes viravam personagem principal.

Esse é também o caso da foto de Militão, ${ }^{\text {II }}$ que retratou um orgulhoso senhor junto com sua escravaria. Nada mais natural, ao menos nesse contexto em que a escravidão, de tão espalhada, quase parecia “óbvia", enquanto mão de obra necessária. Vale destacar, igualmente, que como o sistema era legal e justificado, à época, não havia motivos para que o senhor escondesse sua propriedade: ao contrário, ela era motivo de orgulho e exposição. No entanto, nem o senhor e muito menos o fotógrafo conseguiam domar o oceano de sentimentos expressos nas faces de cada um dos empregados.

Na figura I4 é possível perceber a tensão congelada e encapsulada momentaneamente no estúdio. Ligeiramente à frente está o senhor, com sua expressão cerrada e digna, traje completo, braços cruzados, barba e cabelos aparados, botas e gravata a diferenciá-lo dos demais. Com sua postura corporal e adereços selecionados, ele mostra onde reside a hierarquia. Como mencionamos, longe de esconder, o senhor paga para se ver representado ao lado de seus cativos. Mostrar-se diante de "sua propriedade" era sinal, sem dúvida, da riqueza acumulada e, portanto, motivo de orgulho. E, sim, trata-se indubitavelmente de escravos, pois os companheiros de foto não calçam sapatos e estão numa linha simbólica sutilmente demarcada: ligeiramente atrás do senhor que lhes dá as costas. Mas o anônimo proprietário provavelmente não terá se dado ao trabalho de olhar para trás - ou foi impedido pelo fotógrafo, cioso do resultado de seu ofício - e perceber a reação de cada um de seus escravizados. Indiferença, raiva, constrangimento, impertinência, apatia, melancolia são apenas alguns dos sentimentos expressos nas diversas contrações dos músculos da face. Diferente do que deveria mandar o figurino, ao invés de apresentar posturas compatíveis 


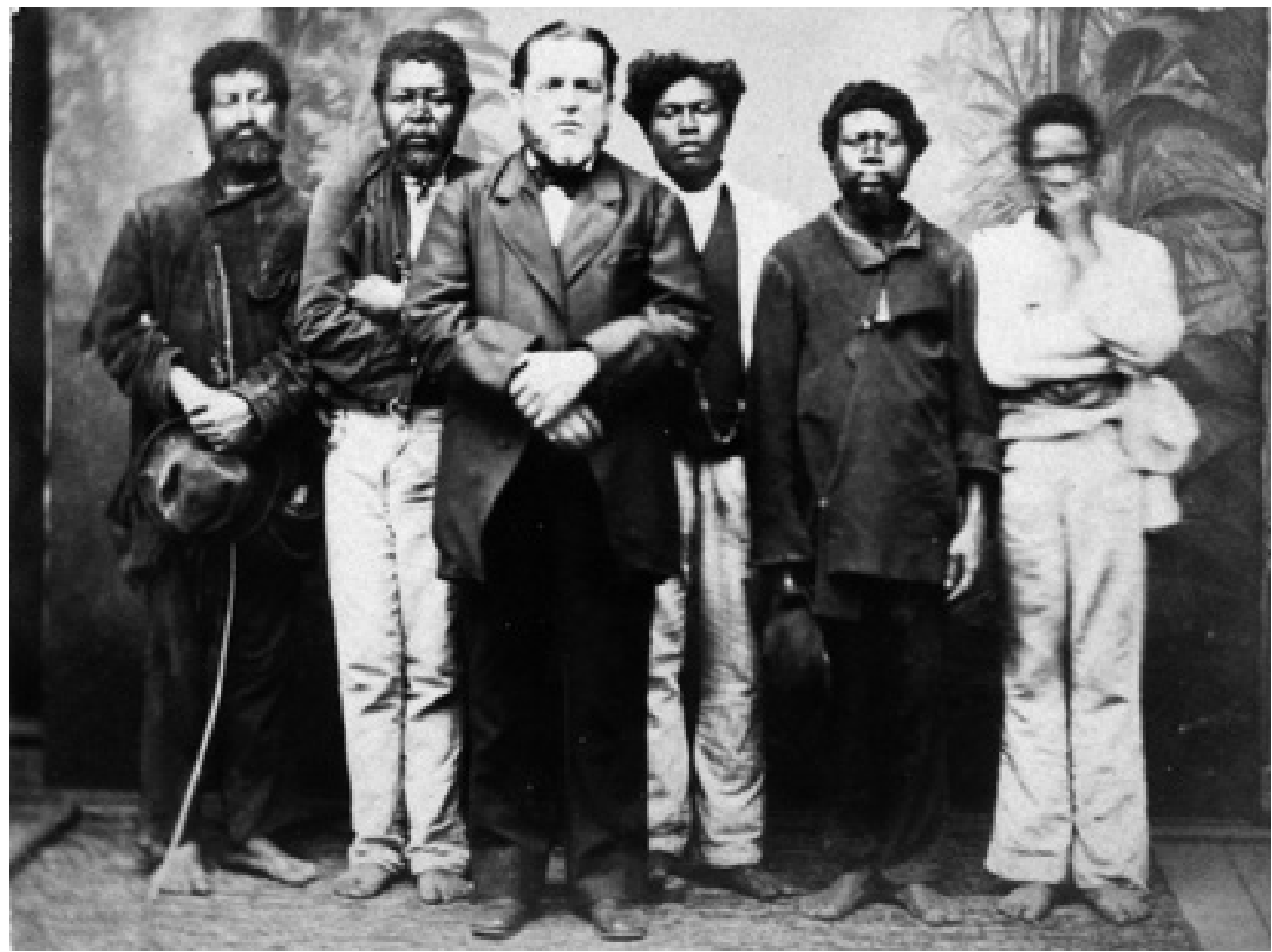

I4

Figura I4.

Militão Augusto de Azevedo.

Senhor e seus escravos. Albúmen,

6,3 × 8,3 cm, São Paulo, s.d.

Álbum de provas do fotógrafo $n^{\circ} 6$,

foto Io.I65.

Fotografia: Hélio Nobre/José Rosael.

Acervo Museu Paulista/USP. 
com suas situações, nesse caso cada um reagiu com sua individualidade. Todos observam a câmara, mas as respostas são as mais variadas. Quem sabe fosse essa também a intenção de Militão, ele próprio um abolicionista convicto (Araújo, 2010). Quem sabe tudo falhou e a foto restou no ateliê de Militão e não foi adquirida pelo senhor de escravos, que provavelmente não gostou do resultado. Quem sabe o profissional tenha ele próprio rejeitado a foto, uma vez que um dos cativos se mexeu, e estragou o resultado final. Esses são pequenos silêncios. O certo é que, nesse exemplo, cada um dos figurantes se reinventou, e criou para si um personagem. Enquanto o senhor seguiu a norma, já os demais produziram para si novos papéis e lugares: possíveis e passageiros jogos de liberdade. Pequenas agências, estratégias de reconhecimento e pertença mediadas pela imagem e que de alguma maneira trapaceiam com as determinações do fotógrafo, do comandatário e do próprio fotografado.

\section{CONCLUSÃO: VER E LER IMAGENS}

Mas essa já é outra história, cheia de novas memórias feitas de imagens visuais que se colam como registros de verdade, de maneira que é muitas vezes difícil separar o que de fato ocorreu e o que o ato fotográfico ou outras formas de imagística imortalizaram. Conforme dizia o relato do jornalista eufórico com a chegada da fotografia na primeira metade do XIX - "é preciso ver a coisa com olhos vistos". Mas "ver a coisa com olhos vistos" não implica, por certo, abrir mão das condicionantes sociais de qualquer imagem, de analisar a clientela, investir na história dos artistas, ou na recepção dos objetos visuais. Compreender os andaimes da produção social das imagens; os trabalhos de seleção, que implicam políticas de favorecimento, de esquecimento ou de proposital destaque são, com certeza, procedimentos necessários para todo aquele que queira enfrentar esse tipo de material.

No entanto, não parece possível (e muito menos desejável) diminuir a relevância de estudos mais internos das obras, atentando igualmente para as características de gênero, os vínculos do pintor com os padrões e convenções de época, as diferentes historicidades presentes e em disputa. Essas são uma espécie de técnicas sintáticas e semânticas à disposição do artista pictórico; uma linguagem da arte ou uma "linguística da imagem", como quer Gombrich (I995). Essa perspectiva nos anima a introduzir, ao lado de nossa forma de entender a expressão verbal, a ideia de "linguagem visível". Termos como imaginação, forma, figuração, imitação, passam a ter um sentido gráfico e icônico e escapam dessa era obcecada pela "textualidade" e em que a "escritura" se converteu em palavra de ordem. Isso sem esquecer da circulação e recepção dessas imagens, e em diferentes momentos. 
Por essas e por outras é que procuramos fazer um diálogo com questões que vêm alimentando não só a história da arte, per se, como a área de Pensamento Social, por exemplo. Ao invés de assumir um dos lados da dicotomia, que opõe historicistas a estruturalistas, formalistas a externalistas, quem sabe seja melhor partido optar pelo diálogo e manter a tensão, positiva, entre as duas perspectivas. Melhor pensar em modelos intercambiados entre mensagens verbais e visuais, entre níveis conotados e denotados (Barthes, 1977). Grosso modo, uma conotação é o que está sempre presente na imagem, enquanto denotação seria o material que interpretamos com e na imagem. Mas esse paradoxo estrutural apenas coincide com o paradoxo que tentamos, eticamente, evitar, quando pensamos existir uma posição "neutra e objetiva" - que apenas copia a realidade de forma meticulosa - e outra mais interativa, e por isso "ideológica". Essa oposição na prática não existe, uma vez que, como vimos, as imagens sempre refletem sobre si mesmas, são mesmo uma metalinguagem. Outra forma de nomear esse impasse teórico, presente nessa relação infinita entre texto e imagem, seria opor visões mais "ilusionistas", das mais "realistas" (ver Freedberg, I989). O ilusionismo seria a capacidade que as imagens teriam de enganar, assombrar, deslumbrar, cujo exemplo maior seria o trompe-l'oeil, ou, mais atualmente, os efeitos do cinema. Em contraposição o realismo seria a capacidade dos registros visuais mostrarem a "verdade das coisas", a de atuarem como "testemunhos oculares", socialmente autorizados e críveis. Conforme mostra Mitchell (2009), para o realismo a melhor expressão seria: "assim é, pois as coisas são assim”. Já para o ilusionismo: "isso é o que as coisas parecem ser". Mas, mais uma vez, essa parece ser uma falsa questão, até porque realismo e ilusionismo correspondem a posições e relações que circulam e ocupam locais intercambiáveis.

O que interessa recuperar, como diz o crítico Michael Baxandall (2006), são, pois, as "causas de um quadro", ou então a "intenção" que presidiu sua produção e a forma que daí resulta. Isto é, trata-se de "ler" uma tela, mas munidos de outras fontes a contrastar a interpretação: elementos da tradição pictórica do próprio pintor, mas também elementos retirados da história e do contexto. ${ }^{12}$ Assim, "situar" não implica tão somente localizar o contexto político em que a obra foi produzida, mas também enfrentar as convenções artísticas que formaram e informaram o autor.

Para nós cientistas sociais, ou para aqueles interessados numa história social da arte, deparar com uma tela acabada - cujo processo não temos muitas vezes como remontar - leva sempre a um estranhamento. Como reconciliar imagem, escrita, história e lastro social (Salgueiro, 2006: 10)? Em primeiro lugar, uma imagem pode ser vista em $180^{\circ}$, por muitos ângulos e a partir da apreensão de vários sentidos, todos concomitantes. Já a narrativa com a qual estamos habituados a lidar achata, reduz e direciona em geral para apenas um sentido. Foi por isso que Baxandall concluiu que a "descrição" que fazemos 
é, antes, uma representação do que pensamos sobre a obra ou da representação dela, não a tela em si. É esse mesmo autor quem mostra como a tarefa de lidar com imagens acaba sendo, por isso mesmo, sempre um pouco melancólica, pois, para piorar, vivenciamos o paradoxo de escrever sobre algo que, produzido no passado, e apesar de ainda "visível", não guarda mais uma relação óbvia com o presente. Essa é a verdadeira incomensurabilidade da relação entre linguagem e imagem. Pode-se dizer que o que "vemos" é quase um exercício em vão, mas esse "em vão" é o que fazemos de maneira mais habitual (Mitchell, 2009: 63). Em segundo lugar, é forçoso reconhecer que - a despeito da segurança e comodidade do historicismo - estamos diante de objetos separados do nosso mundo, e que carregam diferentes temporalidades e contextos, por mais que julguemos ser possível lê-los com olhos do presente. Foi Lucien Febvre quem chamou o anacronismo de "pecado mortal do historiador", uma vez que o procedimento "consiste em atribuir, na reconstrução de um evento histórico, o conhecimento posterior, fazendo dele profecia do passado" (Febvre apud Novaes, 2005: 395). Conforme sentenciou Walter Benjamin (I985): "tempo misterioso é essa imagem do passado que a história transforma em coisa sua”. Com efeito, se esse é um problema inescapável, é no mínimo salutar não ler o passado com lentes exclusivamente voltadas para o próprio momento ou para os interesses do pesquisador.

Mas existe um terceiro problema recorrente e presente em muitos usos que nós cientistas sociais fazemos das imagens. Há quem diga que tudo nesse mundo não passa de etnografia e que para olhar basta ver. A influência dessa perspectiva verista é tal que muitas vezes acabamos tomando um artista como um "ilustrador" - destituído de desejo, vontade ou qualquer laivo de parcialidade. No entanto, e conforme afirmou Ernest H. Gombrich (2007: 36), "muitas vezes a forma precede o significado". Segundo ele, esta relação pode ser melhor observada nas pinturas de caráter verista, que muitas vezes despistam, propositadamente, o observador. Segundo Gombrich, mesmo tais obras não extraem sua ilusão de um modelo real, mas a obtém pela maneira com que articulam um conjunto de esquemas visuais básicos (schematas), transmitidos ao longo de gerações e continuamente readaptados e relidos pelos artistas (Gombrich, 2007). Tais modelos visuais podem, no limite, não guardar qualquer correspondência imediata com as formas naturais que supostamente os inspiraram, e, de alguma maneira - como formas - são anteriores aos significados. Assumir tal tipo de partido teórico ajuda a entender como, muitas vezes - e, sobretudo, quando o conhecimento do outro ou da natureza vem mediado por imagens - acabamos sendo "as vítimas passivas, embora voluntárias, de uma ilusão incontornável” (Gombrich, 2007: xvii). Aí residiria não apenas o impasse da pintura verista, mas do próprio paradigma realista na arte ocidental. É a partir dessas lacunas que somos convidados a desconfiar das aparências codificadas de certas imagens, bem como dos "con- 
textos mentais" - convenções ou memórias de esquemas aprendidos. Logo, se as imagens propõem modos de ver, valem-se do fato de compartir com seu público-alvo determinados contextos mentais e esquemas visuais.

Há qualquer coisa de previsível, mas também de misterioso no ato de analisar imagens. Por um lado, tudo parece fácil, já que não há quem não possa "ver" e assim admirar uma obra de arte. Mas da mesma maneira como se deixam compreender de imediato, essas mesmas obras carregam lá seus segredos, genealogias e historicidades que pedem calma e cuidado: mais do que apenas "olhar", quem sabe seja bom começar a "ler" imagens.

Recebido em 03/02/20I4 | Aprovado em I6/04/20I4

Lilia Moritz Schwarcz é doutora em Antropologia

Social pela Universidade de São Paulo (USP) e historiadora.

É professora titular da USP, Global Scholar na Princeton

University até o ano de 20I8, e foi pesquisadora e professora visitante em diversas prestigiosas

universidades estrangeiras. É autora de vários livros, dentre eles Espetáculo das raças (I993) e As barbas do imperador (1998). Recentemente, dirigiu a coleção História do Brasil Nação em seis volumes, e publicou, em co-autoria com Adriana Varejão, Pérola imperfeita: a história e as histórias na obra de Adriana Varejão (20I4). 


\section{NOTAS}

* Este texto é pautado em duas palestras por mim ministradas: a primeira em Princeton (em março de 2013) e a segunda na Anpocs (em outubro de 2013). Foi ideia de André Botelho que eu transformasse as anotações em um artigo. Esclareço que, mesmo assim, optei por manter o tom mais coloquial das palestras, também aqui. Agradeço ao Maurício Hoelz por todo o seu trabalho na coleta das autorizações das imagens e no estabelecimento final do texto. Agradeço, também, às leituras cuidadosas de Maria Helena Machado e de André Botelho. A ele devo também o incentivo e o "empurrão" para perseverar nesse ensaio. Por essas e por tantas outras esse artigo é a ele dedicado.

I Ver esse debate em Heidegger (1977).

2 O imperador foi inclusive pioneiro quando concedeu seu real patrocínio a um fotógrafo, já em 8 de março de I85I. Nessa época, deu o título de "Photographos da Casa Imperial" a Buvelot e Prat, antecipando-se em dois anos à rainha Vitória, que tratará de criar cargos e titulações semelhantes na Corte inglesa, anos depois.

3 No meu livro As barbas do Imperador (2000), tive oportunidade de tratar desse tema com mais vagar e analisar de que maneira obras como a de Gonçalves Magalhães e Gonçalves Dias dialogavam diretamente com as telas de artistas, igualmente financiados pelo Imperador, como Victor Meireles e Pedro Américo. No livro também trato da correlação de Pedro II com a fotografia.

4 Boris Kossoy foi quem me chamou a atenção sobre esse aspecto.

5 Albert Frisch (Alemanha ca.I840 - s.l. ca.1905) atuou como fotógrafo no Brasil durante a década de I86o. Em companhia do engenheiro, fotógrafo e desenhista Franz Keller-Leuzinger fotografou o Alto Amazonas em I865. Retratou os Umauás com suas armas e paramentos típicos; registrou aspectos das malocas originais, dos ranchos de pesca ao pirarucu e das habitações híbridas dos Tapuias (índios destribalizados sediados nas cercanias de Manaus). Recebeu menção honrosa na Exposição Universal de Paris (França) em i867. 
6 Esses eram retratos em tamanhos bastante fixos (em geral $6 \mathrm{~cm} \times 9 \mathrm{~cm}$ ), e faziam o gosto da clientela, ávida por esse novo tipo de representação. Utilizava-se normalmente uma câmara com lentes múltiplas, que permitiam a obtenção de quatro a oito fotos em um mesmo negativo. Eram reproduzidos em folha de papel, e só então recortados e colados em um papelão mais encorpado, cujo verso servia para a propaganda e informação da casa fotográfica que realizara o serviço.

7 Para mais informações sobre os fotógrafos do Império e aqueles financiados pelo Imperador sugiro a leitura de Kossoy (2002); Kossoy \& Schwarcz (2012); Fernandes Jr. (2000); Ferrez, G. (1985); Ferrez, M. (2005); Freyre, Ponce de Leon \& Vasquez (I983); Haeynemann \& Rainho (2005); Lago, B. (200I); Lago \& Lago (2005).

8 A princesa Isabel foi discípula de Revert Klumb, que recebia por suas aulas particulares de fotografia 400 mil réis por ano. No livro de Receitas e Despesas da Casa Imperial, D. Pedro, no período de 1848 e I867, gastou em fotografias de Buvelot, 730\$000; com Victor Frond, 9:I27\$000; Joaquim Insley, 243\$000; Stahl, 730\$000; Henrique Klumb, 2:8I5\$00o; Carneiro \& Gaspar, I:600\$00o; Carneiro \& Smith, I:045\$00o; Casa Leuzinguer, 237\$000, totalizando I8 contos 796 mil réis. Foram comprados, ainda, álbuns de Victor Frond e de outros fotógrafos, o que eleva a conta a um total de 22 contos e 528 mil réis, e corresponde a trinta vezes o valor que o imperador teria recebido para seus gastos pessoais no ano de 1846 .

9 Se o próprio imperador era um fotógrafo, acabou por incentivar outros profissionais em atividade no país. Insley Pacheco foi o mais frequente e íntimo fornecedor de imagens da família, mas não o único. Dizia-se que Buvelot e Prat eram os daguerreotipistas favoritos dos monarcas. Também Klumb se esmeraria para ficar próximo dos reais governantes e usaria de suportes até mais originais que o papelão, como o singelo guardanapo onde estampou o retrato da princesa Leopoldina. De todos os profissionais que cercaram D. Pedro, August Stahl é considerado o mais talentoso. 
Io Gombrich (2007) usa o conceito de série iconográfica como procedimento metodológico para mostrar a maneira como as obras dialogam entre si criando verdadeiras culturas e referências visuais.

I I Sobre Militão, esse fotógrafo que se radicou em São Paulo em finais do XIX, ler e ver, entre outros: Carvalho (I99I); Carvalho \& Lima (2004, I997); e Lago (200I).

I 2 Ver, também, a excelente introdução de Heliana Angotti Salgueiro para a própria obra de Baxandall (2006). Conforme mostra Heliana Salgueiro, é difícil lidar com "o ato de descrever e o de visualizar" (2006: I0). Distância, descompasso e diferença cultural são conceitos que marcam essa relação.

\section{REFERÊNCIAS BIBLIOGRÁFICAS}

Alloula, Malek. (I986). The colonial harem. Minneapolis: University of Minnesota Press.

Anderson, Benedict. (2009). Comunidades imaginadas. São Paulo: Companhia das Letras.

Araújo, Íris Morais. (20Io). Militão Augusto de Azevedo: fotografia, história e antropologia. São Paulo: Alameda.

Barthes, Roland. (I977). The photographic message. In: Image, music, text. Nova York: Hill and Wang, p. I5-3I.

Baxandall, Michael. (2006). Padrões de intenção. São Paulo: Companhia das Letras.

Benjamin, Walter. (1985). Sobre o conceito de história. In: Obras escolhidas I: magia e técnica, arte e política. São Paulo: Brasiliense.

Bhabha, Homi. (2002). O lugar da cultura. Belo Horizonte: Ed. UFMG.

Bloch, Marc. (I980). Os reis taumaturgos. São Paulo. Companhia das Letras.

Brizuela, Natalia. (20I2). Fotografia e Império: paisagens para um Brasil moderno. São Paulo: IMS/Companhia das Letras. Cadava, Eduardo \& Cortés-Rocca, Paola. (2006). Notes on love and photography. October, II6, p. 3-34.

Carvalho, Vânia Carneiro de. (I99I). A representação da natureza na pintura e na fotografia brasileiras do século XIX. In: Fabris, Annateresa (org.). Fotografia: usos e funções no século XIX. 2. ed. São Paulo: Edusp, p. I99-23I. 
Carvalho, Vânia Carneiro de \& Lima, Solange Ferraz de. (2004). Militão e a paisagem possível. In: Barbosa, Gino Caldatto (org.). Santos e seus arrabaldes: álbum de Militão Augusto de Azevedo. São Paulo: Magma Cultural.

Carvalho, Vânia Carneiro de \& Lima, Solange Ferraz de. (I997). Fotografia e cidade: da razão urbana à lógica do consumo: álbuns de São Paulo (I887-I954). Campinas: Mercado de Letras.

Cunha, Manuela Carneiro da. (2000). História dos índios no Brasil. São Paulo: Companhia das Letras.

Darnton, Robert. (1978). O grande massacre de gatos e outras histórias culturais na França. Rio e Janeiro: Paz e Terra.

Fernandes Jr., Rubens. (2000). Século XIX na fotografia brasileira. São Paulo: Fundação Armando Álvares Penteado.

Ferrez, Gilberto. (I985). A fotografia no Brasil, I840-I900. Rio de Janeiro: Fundação Nacional Pró-Memória.

Ferrez, Marc. (2005). O Brasil de Marc Ferrez. São Paulo: IMS. Freedberg, David. (1989). The power of images: studies in the history and theory of response. Chicago: Chicago University Press.

Freyre, Gilberto; Ponce de Leon, Fernando \& Vasquez, Pedro. (I983). O retrato brasileiro: fotografias da Coleção Francisco Rodrigues I840-I920. Recife: Funarte/Fundação Joaquim Nabuco.

Geertz, Clifford. (I975). Interpretação das culturas. Rio de Janeiro: Zahar.

Goethe, Johann Wolfgang von. (I999). Viagem à Itália (I786I788). São Paulo: Companhia das Letras.

Gombrich, Ernst H. (2007). Arte e ilusão: um estudo da psicologia da representação pictórica. São Paulo: Martins Fontes.

Haeynemann, Cláudia \& Rainho, Maria do Carmo (orgs.). (2005). Retratos modernos. Rio de Janeiro: Arquivo Nacional. Heidegger, Martin. (1977). The age of the world picture. In: The question concerning technology and other essays. Nova York: Harper \& Row, p. II5-I54.

Kossoy, Boris. (2002). Dicionário histórico-fotográfico brasileiro: fotógrafos e ofício da fotografia no Brasil (I833-I9IO). São Paulo: Instituto Moreira Sales. 
Kossoy, Boris. (2000). Hercule Florence. São Paulo: Edusp.

Kossoy, Boris. (I980). Origens e expansão da fotografia no Brasil: século XX. Rio de Janeiro: Funarte.

Kossoy, Boris \& Schwarcz, Lilia. (2012). Um olhar sobre o Brasil. Rio de Janeiro: Objetiva.

Lago, Bia Corrêa do. (200I). Augusto Stahl: obra completa em Pernambuco e Rio de Janeiro. Rio de Janeiro: Capivara.

Lago, Bia \& Lago, Pedro Corrêa do. (2005). Os fotógrafos do Império: a fotografia brasileira do século XIX. Rio de Janeiro: Capivara.

Lago, Pedro Corrêa do. (200I). Militão Augusto de Azevedo. Rio de Janeiro: Capivara.

Le Goff, Jacques. (I976). História: novos problemas. São Paulo: Martins Fontes.

Lipman, Jean \& Marshall, Richard. (1978). Art about art. Nova York: E. P. Dutton/Whitney Museum of American Art. Mauad, Ana Maria. (1997). Imagem e auto-imagem do Segundo Reinado. In: Alencastro, Luiz Felipe de (org.). História da vida privada no Brasil. Império: a corte e a modernidade nacional. São Paulo: Companhia das Letras, p. I8I-23I. (vol. 2)

McClintock, Anne. (20Io). Couro imperial. Campinas: Ed. Unicamp.

McClintock, Anne. (2003). Couro imperial: raça, travestismo e culto da domesticidade. Cadernos Pagu, 20, p. 7-85.

Mitchell, William John Thomas. (2009). Teoria de la imagen. Madrid: Akai.

Novaes, Fernando. (2005). Aproximações. São Paulo: Cosac Naif. Reis, Daniel Aarão (org.). (20I4). História do Brasil nação. Modernização, ditadura e democracia. Rio de Janeiro: Mapfre/ Objetiva (vol. 5).

Said, Edward. (1986). After the last sky: Palestinian lives. Fotografias de Jean Mohr. Nova York/Londres: Pantheon/Faber. Sahlins, Marshall. (I997a). O "pessimismo sentimental” e a experiência etnográfica: por que a cultura não é um “objeto" em via de extinção (parte I). Mana, 3/I, p. 4I-73.

Sahlins, Marshall. (I997b). O "pessimismo sentimental" e a experiência etnográfica: por que a cultura não é um "objeto" em via de extinção (parte II). Mana, 3/2, p. I03-I50. 
Salgueiro, Heliana Angotti. (2006). Introdução à edição brasileira. In: Baxandall, Michael (org.). Padrões de intenção. São Paulo: Companhia das Letras, p. 9-23.

Schama, Simon. (1996). Paisagem e memória. São Paulo: Companhia das Letras.

Schwarcz, Lilia Moritz. (2000). As barbas do imperador. São Paulo: Companhia das Letras.

Vasquez, Pedro Karp. (2003). O Brasil na fotografia oitocentista. São Paulo: Metalivros.

Vasquez, Pedro Karp. (200I). Revert Henrique Klumb: um alemão na corte imperial brasileira. Rio de Janeiro: Capivara. Vasquez, Pedro Karp. (I985). D. Pedro II e a fotografia no Brasil. Rio de Janeiro: Index.

Williams, Raymond. (I989). O campo e a cidade. São Paulo: Companhia das Letras.

\section{CRÉDITOS DAS IMAGENS}

I. Augusto Stahl. Cachoeira de Paulo Afonso, Rio São Francisco, Alagoas, I86-. Stahl \& Ca., Photographos de S. M. o Imperador do Brasil. Papel albuminado, p\&b, 26 x $56 \mathrm{~cm}$. Acervo Fundação Biblioteca Nacional.

2. Revert Henry Klumb. Tijuca/La petite cascade, Rio de Janeiro, c. I860. Albúmen. Acervo Fundação Biblioteca Nacional.

3. Albert Frisch. Índios Umauá na antiga Província do Alto Amazonas, região do rio Solimões, Província do Alto Amazonas (atual região do rio Solimões), Amazonas, c. I867. Albúmen, $23,8 \times$ I $8,3 \mathrm{~cm}$, fotomontagem. Convênio Instituto Moreira Salles/Leibniz-Institut für Laenderkunder.

4. Marc Ferrez. Chefe da tribo de índios Appiacaz, no Amazonas, Amazonas, I887. Albúmen, I5,5 x 2I cm. Acervo Museu Imperial/Ibram $/ \mathrm{MinC} / \mathrm{n}^{\circ} 43 / 2014$.

5. Marc Ferrez. Jovem índio do Mato Grosso, c. I88o. Albúmen, $23,9 \times 17,9 \mathrm{~cm}$. Acervo Instituto Moreira Salles.

6. Marc Ferrez. Índios Bororo, Goiás, c. I880. Albúmen, 2I, 2 X 25,8 $\mathrm{cm}$. Coleção Gilberto Ferrez. Acervo Instituto Moreira Salles.

7. Sebastien Auguste Sisson. D. Pedro II, Rio de Janeiro, I86I. Litografia baseada em foto. In: "Galeria dos Brasileiros Ilustres" ("os contemporâneos") (volume I). Biblioteca Brasiliana Guita e José Mindlin - USP. 
8. Carneiro \& Gaspar. A Imperatriz Teresa Cristina observando a si mesma e D. Pedro II conversando consigo mesmo, Rio de Janeiro, c. I867. Papel albuminado, carte-de-visite, 9 × 6 cm. Acervo do Arquivo Grão Pará.

9. Pedro Américo de Figueiredo e Mello. Pedro II na Abertura da Assembleia Geral, I872. Óleo sobre tela, $288 \mathrm{~cm} \mathrm{X} 205 \mathrm{~cm}$. Acervo Museu Imperial/Ibram/MinC/n43/2014.

Io. Francisco Manuel Chaves Pinheiro. Alegoria do Império Brasileiro, I872. Terracota modelada, $192 \times 75 \times 3 \mathrm{I} \mathrm{cm}$. Fotografia: Jaime Acioli. Coleção Museu Nacional de Belas Artes/IBRAM/MinC $/ \mathrm{n}^{\circ} 25 / 2014$.

II. Angelo Agostini. Caricatura de D. Pedro II. Revista Ilustrada, n. 310, I882. Acervo Fundação Biblioteca Nacional.

I2. Joaquim Insley Pacheco. Pedro II, Imperador do Brasil, Rio de Janeiro, I883. Platinotipia, p\&b; 37,5 x 29,2 cm. Acervo Fundação Biblioteca Nacional.

I3. Fotógrafo não identificado. Senhora na liteira com dois escravos, Bahia, c. I860. Albúmen, 5,5 × 8, I cm. Acervo Instituto Moreira Salles.

I4. Militão Augusto de Azevedo. Senhor e seus escravos. São Paulo, s.d. Albúmen, 6,3 × 8,3 cm. Álbum de provas do fotógrafo $n^{\circ} 6$, foto I0.I65. Fotografia: Hélio Nobre/José Rosael. Acervo do Museu Paulista/USP. 
Palavras-chave

Imagens;

Iconografia;

Segundo Reinado;

Metodologia;

Representação.

Keywords

Images;

Iconography;

Second Reign;

Methodology;

Official depictions.

\section{LENDO E AGENCIANDO IMAGENS:}

\section{O REI, A NATUREZA E SEUS BELOS NATURAIS}

\section{Resumo}

O artigo parte de uma "provocação metodológica": por que nós, cientistas humanos de uma maneira geral, somos tão cuidadosos com os documentos escritos, e tão conservadores quando lidamos com fontes iconográficas? Por que nos preocupamos em dar todas as referências quando analisamos livros, fontes, cartas, atas e já os documentos imagéticos são tratados como mera "ilustrações", no sentido de que só dão "lustro" e adornam o que previamente sabemos? Partindo dessas questões procurase explorar o tema a partir da análise de um conjunto documental produzido durante o Segundo Reinado, quando o monarca e os governantes que os cercavam trataram de desenhar a nacionalidade a partir de um tripé, fartamente composto por imagens oficiais do Estado: o rei, a natureza e seus naturais (entre escravos e indígenas). O desafio é, pois, analisar de que maneira imagens não só reproduzem (são produtos), mas ajudam a produzir o contexto em que se inserem.

\section{READING ICONOGRAPHY AND THE} AGENCY OF IMAGES: THE KING, NATURE AND HIS BEAUTIFUL NATIVES

\section{Abstract}

The main goal of this article is a methodological one. Why we, human scientists in general, are so careful about written documents, but so conservative dealing with iconographic sources? How to understand the importance of images as an historical document? How to deal with visual documents not as mere "illustrations", which are only meant to give luster and adorn what is a priori known, or "products" of their context, but as a main source of "production" of costumes, representations, and depictions of a particular moment? Having this kind of questions in mind, the article analyses a set of documents produced during the Second Reign, when Pedro II and his governors tried to create a kind of official project of nationality on a tripod basis formed by official images of the State: the king, nature, and his natives (slaves and indigenous people). The challenge then is to analyze how images not only reproduce (are products of) but also produce the context in which they are inscribed. 